\title{
Europe's 'Other' Open-Border Zone: The Common Travel Area under the Shadow of Brexit
}

\author{
Graham BUTLER \\ Aarhus University, Denmark \\ Gavin BARRETT \\ University College Dublin, Ireland
}

\begin{abstract}
In recent years, the Schengen Area-and the suppression within its territory of border controls-has become a strong focus of attention. This article focuses on another region of Europe where such controls have been suppressed: the Common Travel Area ('CTA'). Historically, both Ireland and the United Kingdom have rejected membership of the Schengen system — albeit securing certain 'opt-in' rights—and instead maintained the CTA between their respective jurisdictions. The CTA has, however, garnered relatively little public attention until recently, when concerns as to the implications of Brexit for the maintenance of an open border between Ireland and Northern Ireland have gained ground, and threatened to be a deal breaker in the negotiations under Article 50 TEU on UK exit from the EU ('Brexit'). This article examines the background to the CTA, exploring its surprisingly fluid legal framework; its development in the legal systems of Ireland and the United Kingdom; and subsequently, how it was exempted from what is now EU law as the Schengen arrangements were integrated into the Union. The recent introduction of the British-Irish Visa Scheme, which formalises some visa rules regarding citizens of third states, and which tends in the direction of consolidating CTA arrangements, is also examined. The article further explores the challenges that confront the CTA in coping with the outcome of the June 2016 Brexit referendum, which should result in the UK leaving the European Union in March 2019, and the implications of Brexit for the CTA. Finally, it seeks to identify some key characteristics of the CTA in light of experience to date.
\end{abstract}

Keywords: Common Travel Area, protocols, European Union, freedom of travel, Schengen, United Kingdom and Ireland, opt-out, Brexit

\section{INTRODUCTION}

Borders are back—back in the news, and back as a political issue of such import that they are capable of commanding attention at the highest level, and in extremis, even bringing down governments. The phenomenon is Europe-wide, whether one looks at Italy, where a government that swept into power partly due to migration concerns is now seeking to reduce the number of migrants arriving in Italian ports with means 
which have included denying rescue vessels permission to disembark at its ports; ${ }^{1}$ Spain, where difficulties enforcing border controls at the enclave of Ceuta and controlling entry along Spain's Mediterranean coast have coincided with the sharply increased politicisation of the issues of migration and border control; ${ }^{2}$ central Europe, where the Hungarian government in particular has taken a resolutely anti-migrant stance, including both the construction of a border fence with neighbouring Serbia and the introduction of indefinite detention for asylum seekers who cross its borders, ${ }^{3}$ and Austria, where the chancellor recently threatened the reintroduction of border controls with Italy, and has questioned the ability of the Schengen zone to survive challenges posed by migration without tougher external border controls. ${ }^{4}$ Meanwhile, a border-related dispute has for long constituted the single greatest threat to the successful conclusion of ongoing Brexit negotiations. 5

While there is no shortage of research on the Schengen area-with its longstanding suppression of border controls between EU Member States-a less-studied free travel area within the European Union is the Common Travel Area ('CTA') in which border controls have been suppressed for many decades for travel between the United Kingdom and Ireland. The CTA has been described as an area within which 'internal borders are subject to minimal or non-existent border controls' ${ }^{6}$ In practice, it allows for freedom of travel across the border between Northern Ireland and Ireland, largely as if no international frontier existed. The position regarding control on arrivals by sea and air is more complex. In practice, arrivals by sea in Ireland are not subject to passport checks, but, arrivals at Irish airports are subject to such checks. Irish and UK citizens are exempt from Irish immigration law as a whole, but nonetheless need to be able to show their status at passport control points. Under UK law, in contrast, immigration control is not applied to the CTA as a matter of law. Hence, the CTA is not as robust as is popularly imagined. First, limitations on free travel exist, depending on the direction of travel. Secondly, passport-free travel is not made available to all persons in either jurisdiction. It is worth noting in this context

1 See J Politi, 'Malta Allows Migrant Rescue Vessel to Dock, Ending Stand-Off' (Financial Times, 24 June 2018); ‘Trump Hails Italy's Actions on Migration' (Financial Times, 31 July 2018).

2 See I Mount, 'Casado Seeks to Put Migration at Centre of Spanish Political Debate' (Financial Times, 30 July 2018).

3 See A Sandford, 'Hungary Completes New Anti-Migrant Border Fence with Serbia' (Euronews, 28 April 2017); V Hopkins and M Peel, 'Hungary Defends Anti-Migrant Stance in the Face of EU Action' (Financial Times, 19 July 2018).

4 See G Chazon and R Atkins, 'German Migrant Deal Prompts Austrian Border Threat' (Financial Times, 3 July 2018); M Peel, 'Austria’s Sebastian Kurz Urges EU to Bolster Border Forces Quickly' (Financial Times, 5 July 2018).

5 See eg S Carswell, 'Barnier Tries to Calm Politics Around Unresolved Border Issue' (Irish Times, 1 May 2018); T Connelly, 'Brexit Breaking Point: The Tory Civil War and the Irish Border' (RTÉ, 28 April 2018); L Hughes, 'Theresa May Urges EU to Help Resolve Irish Border Issue' (Financial Times, 20 July 2018); D. Sabbagh, D. Boffey and J. Rankin, 'Time Running Out as Theresa May Claims Brexit Talks in the "Endgame"" (The Guardian, 2 November 2018).

6 Oireachtas Joint Committee on European Union Affairs, Report on the UK/EU Future Relationship: Implications for Ireland (Houses of the Oireachtas (Irish Parliament), June 2015). 
that the two states enforce each other's conditions of entry, whenever non-nationals of either state seek to enter either jurisdiction with the intention of travelling on to the other, without qualifying for admission there. ${ }^{7}$ Notwithstanding these limitations, however, the CTA clearly results in considerable inconvenience being avoided by its beneficiaries. It is somewhat remarkable that there is no international treaty of any kind establishing the CTA. It has come about and operated without the benefit of any framework document outlining its objectives and features. Perhaps partly in consequence, it has largely escaped rigorous discussion or criticism by a general public which has largely taken it for granted, even while benefiting from its existence.

Although the CTA existed well before the creation of what is now the EU, and does not in any way owe its existence to the EU, its continued operation is, nonetheless, facilitated by a derogation from EU law, and in particular from the Schengen acquis. It is the subject of a specific Protocol on border controls annexed to the Treaty on European Union (TEU) and the Treaty on the Functioning of the European Union (TFEU) - Protocol (No 20) on 'the application of certain aspects of Article 26 of the Treaty on the Functioning of the European Union to the United Kingdom and to Ireland'. In fact, a rather impressive array of opt-outs from EU law benefits the United Kingdom and Ireland. Hence, apart from Protocol (No 20)_which relates specifically to the CTA-there is also Protocol (No 19) on 'the Schengen acquis integrated into the framework of the European Union', which facilitates the position of Ireland and the United Kingdom as the only two states in Western Europe outside the Schengen arrangements. ${ }^{8}$ Since the entry into force of the Treaty of Lisbon, there

\footnotetext{
7 Note as regards UK law, the provisions of the Immigration (Control of Entry through Republic of Ireland) Order 1972 (as amended), which lists categories of person deemed to have leave for three months on arrival from Ireland. These include all EU nationals and also nationals from third countries that do not require a visa to enter the United Kingdom and who are lawfully in Ireland. As regards Irish law, this was summarised by the Minister of State at the Department of Education and Skills, Damien English TD, during the Second Stage debate on the Freedom of Movement (Common Travel Area) (Travel Documentation) Bill 2014 in the Dáil, where he observed that:
}

[S]ection 4(3)(h) of the Immigration Act 2004 ... empowers an Irish immigration office to refuse entry to the State to a non-national where the officer is satisfied that the non-national intends to travel, whether immediately or not, to Great Britain or Northern Ireland, and would not qualify for admission to Great Britain or Northern Ireland if he or she arrived there from a place other than the State. To that end it is, and has always been, the case that there is close co-operation between the Irish and British immigration authorities on a strategic and operational basis.

${ }^{8}$ Under the terms of Article 4 of Protocol (No 19) on the Schengen acquis integrated into the framework of the European Union, either state may at any time request to take part in some or all of the provisions of the Schengen acquis and the Council shall decide on the request with the unanimity of those EU Member States participating in Schengen and the state concerned. Article 5 of the same Protocol, makes provision for proposals and initiatives to build upon the Schengen acquis and for Irish and United Kingdom participation where either state wishes to take part in the areas of cooperation in question (where the state has at first failed to notify the Council in writing within a reasonable period that it wished to take part). It provides as well as for a change of mind by either state about opting-in to the adoption of a measure under Article 4. 
is also Protocol (No 21) on 'the position of the United Kingdom and Ireland in respect of the area of freedom, security and justice', which involves a broader opt-out with an opt-in in the justice and home affairs field generally. ${ }^{9}$

This article analyses the CTA from a number of standpoints. ${ }^{10}$ It considers the history of the CTA; its respective national legislative bases in both UK and Irish law, as well as its interaction with EU law. It looks at how judicial developments have affected the operation of the CTA, and also considers contemporary developments and challenges facing the CTA-specifically, the closer integration of UK and Irish visa regimes, and in particular, the mutual recognition by the UK and Ireland of visas of non-EU third country nationals under the British-Irish Visa Scheme. Finally, this article also looks at Brexit, which will bring with it the strongest challenge to the CTA's ongoing relevance, and perhaps in the medium term, to its very existence.

In doing all of this, the article seeks to identify a number of the most important characteristics of the CTA, and in this way, to better understand the extent of its capacity to survive the challenge of being - post-Brexit-a CTA where one party, the UK, is outside the EU and another party, Ireland, remains within the EU. It will be seen that at least eight key features have come to characterise the CTA. These have been: first, its extraordinary decades-long durability through a variety of challenging circumstances; secondly, the surprising - if now gradually ebbingdegree of informality that exists in the CTA's framework and operation; thirdly, its rather fluid and evolving nature; fourthly - to some extent as a corollary-the fragility of the benefits the CTA offers; fifthly, that the phenomenon of engrénage-the fact that "way leads on to way' ${ }^{11}$ — can be seen to apply to the CTA; sixthly, the lack of uniformity between the UK and Ireland regarding the respective national interests served by the CTA, the respective means used to implement the CTA, and the mutual

9 Other Protocols now applying to the United Kingdom such as Protocol (No 30) on the application of the Charter of Fundamental Rights of the European Union to Poland and to the United Kingdom and Protocol (No 15) on certain provisions relating to the United Kingdom of Great Britain and Northern Ireland, which exempts the United Kingdom from the obligation to adopt the euro as its currency, while not entirely irrelevant, are nonetheless not sufficiently germane for the purposes of the present article to warrant further attention.

${ }^{10}$ See for some earlier legal scholarship on the CTA, E Meehan, Free Movement between Ireland and the UK: From the 'Common Travel Area' to the Common Travel Area (Policy Institute, 2000); B Ryan, 'The Common Travel Area between Britain and Ireland' (2001) 64(6) Modern Law Review 855; E Fahey, 'Swimming in a Sea of Law: Reflections on Water Borders, Irish (British) Euro Relations and Opting-Out and Opting-In after the Treaty of Lisbon' (2010) 47(3) Common Market Law Review 673; E Fahey 'A Jagged-Edged Jigsaw: The Boundaries of Constitutional Differentiation and Irish-BritishEuro Relations after the Treaty of Lisbon' in M Trybus and L Rubini (eds), The Treaty of Lisbon and the Future of European Law and Policy (Edward Elgar, 2012); D McGuinness, 'Has the Common Travel Area a Future?' in Freedom, Security and Justice after Amsterdam (unpublished paper, 1998); G Hogan, 'The Common Travel Area and Community Law' in N Hyland (ed), The Free Movement of Workers within the European Union (Irish Centre for European Law, 1999); G Butler, 'Not a "Real" Common Travel Area: Pachero v Minister for Justice and Equality' (2015) 54 Irish Jurist 155; and I Maher, 'Crossing the Irish Land Border after Brexit: The Common Travel Area and the Challenge of Trade' (2018) 11-12 Irish Yearbook of International Law 51.

11 See R Frost, 'The Road Not Taken' in R Frost, Mountain Interval (Henry Hill, 1916). 
respective influence brought to bear on the Irish and UK legal systems through it; seventhly, the fact that Irish participation in the CTA comes at a certain price in terms of policy freedom; and eighthly, the vital role context plays in determining the CTA's significance, a point of more relevance than ever in the age of Brexit.

\section{THE COMMON TRAVEL AREA CONSIDERED}

\section{A. History}

Freedom of travel in the form of the absence of border controls between the territories of the United Kingdom and Ireland has been an arrangement of strikingly long duration. It is now only half a decade from its hundredth year, having pre-dated the European project by almost thirty years, and pre-dated the Schengen Agreement by over sixty. The CTA arrangements obviously also pre-dated the somewhat similar arrangement existing between some of the Nordic states through the Nordic Passport Union, which was established gradually between 1952 and 1957 and similarly offered citizens of the Nordic states-Denmark, Sweden, Norway, Finland, and Iceland-passport-free travel; ${ }^{12}$ the arrangements introduced by Belgium, the Netherlands, and Luxembourg from 1970 under the auspices of the Benelux economic union; and the Saarbrücken Agreement between France and Germany in 1984, aimed at the abolition of checks at their common border-and to which specific reference was made in the preamble to the Schengen Agreement ${ }^{13}$ —all of which the Schengen Area has now largely, or entirely, subsumed.

Geographically, the United Kingdom and Ireland occupy two islands (respectively the eighth largest and twentieth largest in the world) on the north-western edge of the continent of Europe. The two states are physically linked by a common land border running through the smaller of the two islands. On the north-eastern side of that border on the smaller island is Northern Ireland, a component part of the United Kingdom, the remaining territory of which also comprises the larger of the two islands. The territory of what is now Ireland gained its independence under the terms of the Anglo-Irish Treaty of 1921 as the Irish Free State. Historically, some ambiguity has existed concerning the use of the name 'Ireland'. According to Article 4 of the republican Irish Constitution-adopted in 1937 as Ireland's second constitution, and which remains the basic law right up to the present day- 'the name of the State is Eire, or, in the English language, Ireland'. Article 2 of the same 1937 Constitution originally provided that 'the national territory consists of the whole island of Ireland, its islands and the territorial seas'. ${ }^{14}$ This territorial claim was deleted from Article 2

\footnotetext{
12 See the Nordic Passport Convention, agreed under the auspices of the Nordic Council, 12 July 1957.

13 The Schengen acquis - Agreement between the Governments of the States of the Benelux Economic Union, the Federal Republic of Germany and the French Republic on the gradual abolition of checks at their common borders: [2000] OJ L239, pp 13-18.

14 Article 3 provided: 'Pending the re-integration of the national territory, and without prejudice to the right of the Parliament and Government established by this Constitution to exercise jurisdiction over the whole of that territory, the laws enacted by that Parliament shall have the like area and extent of application as the laws of [the Irish Free State] and the like extra-territorial effect'.
} 
as a result of a May 1998 constitutional referendum as part of the Good Friday Agreement. Article 2, without seeking to provide any definition of the national territory, now merely asserts that it is the entitlement and birthright of every person born in the island of Ireland, which includes its islands and seas, to be part of the Irish Nation'. Somewhat confusingly, without any amendment of Article 4 of the Constitution ever having been effected, Section 2 of the Republic of Ireland Act was adopted in 1948 providing that 'it is hereby declared that the description of the State shall be the Republic of Ireland'. Consequently, 'Ireland' and the 'Republic of Ireland' are used today as alternative descriptions of the state.

Northern Ireland-constituted by six of the nine counties of the northernmost province of Ulster-remained a part of the United Kingdom when the rest of the island of Ireland obtained its independence in 1922. The name 'Northern Ireland' derives from the Government of Ireland Act 1920 which sought to establish separate Home Rule institutions within the United Kingdom for two new subdivisions of Ireland. The 1920 Act never had any practical effect in the rest of Ireland, where the ongoing prosecution of the War of Independence led eventually to the establishment of the Irish Free State in 1922. However, the institutions set up for Northern Ireland under the 1920 Act continued to function until suspended by the British parliament in 1972 in consequence of the outbreak of violence in Northern Ireland at that time. Under the terms of the 1998 Good Friday Agreement, ${ }^{15}$ the remaining provisions of the 1920 Act still in force in Northern Ireland were repealed.

The United Kingdom and Ireland have in common the use of the English language by the overwhelming majorities of both of their populations, and have a high level of mutual trade. ${ }^{16}$ The latter factor provided a key reason for Ireland to join the then European Economic Community ('EEC') at the same time as the UK, which it did on 1 January 1973, alongside Denmark, during the EEC's first enlargement. ${ }^{17}$ The level of closeness between the two states is not solely limited to trade matters however. It applies in a number of areas of public policy, with the two states enjoying extensive cultural, personal, and political links. High levels of interstate migration, largely (although far from exclusively) from Ireland to the United Kingdom, have existed for many decades. Indeed, it is fair to say that migrant nationals from one or other state are not fully seen as foreign in the eyes of the other. In the sensitive area of voting rights, reciprocal voting rights are enjoyed by the citizens of both states in each

15 This Agreement also led to the deletion of the constitutional claim on the territory of Northern Ireland found at that time in Article 2 of the Constitution of Ireland.

16 According to recently published figures, Ireland exports annually $€ 15.6$ billion worth of goods to the United Kingdom and imports $€ 18$ billion worth of goods from there. At the same time Ireland exports $€ 18$ billion worth of services to the UK and imports $€ 11.4$ billion worth in return. See Central Statistics Office (Ireland), Brexit: Ireland and the UK in Numbers (December 2016).

${ }^{17}$ See for details regarding the process of Irish entry into the then Communities, D Keogh and A Keogh, 'Ireland and European Integration: From the Treaty of Rome to Membership' in M Callanan (ed), Foundations of an Ever Closer Union (Institute of Public Administration, 2007). All three states simultaneously joined the European Coal and Steel Community and the European Atomic Energy Community ('Euroatom'), although the key organisation economically and politically was clearly the EEC. 
other's parliamentary elections, ${ }^{18}$ and citizens of both states can be elected to each other's national parliaments. ${ }^{19}$

Freedom of travel between what are now the two states of the United Kingdom of Great Britain and Northern Ireland, on the one hand, and Ireland, on the other, predates the independence of what is now Ireland, and stretches back to a time when the territories of both Northern Ireland and Ireland formed part of the same state, the United Kingdom of Great Britain and Ireland. Prior to 6 December 1922 - the date of the foundation of the Irish Free State-freedom to travel between Britain and Ireland was never in question, since travel within and between the two islands simply constituted travel within the United Kingdom. No provision was made in the Anglo-Irish Treaty that gave birth to the Free State concerning either border controls or freedom of travel issues. It might have seemed premature, in any case, to place checkpoints along a new border, when a Boundary Commission had been entrusted with the politically sensitive task of determining its permanent location. ${ }^{20}$

Between the date of the signature of the Treaty in December 1921 and its entry into force one year later, however, minds turned to this issue. Since the Home Office regarded the introduction of a passport requirement as lacking any advantage to Britain, the offer of dispensing with it was made to the nascent Free State. The offer came at a price, however, and the CTA was thus from its very beginnings the child of an unequal power relationship. No attempt was made to discuss the terms of an agreed immigration regime. Instead, Irish cooperation in enforcing the British immigration system was the price demanded by the UK for the absence of border controls. This offer was probably correctly anticipated by Irish officials to come at little political cost, given that until the dawn of the Celtic Tiger economy in the 1990s, Ireland, as a persistent relative economic underachiever, was to experience relatively little immigration. ${ }^{21}$ At any rate, the early Home Office initiative was

18 See generally, S Day and J Shaw, 'European Union Electoral Rights and the Political Participation of Migrants in Host Polities' (2002) 8(2) International Journal of Population Geography 183, p 194. See generally, J Shaw, The Transformation of Citizenship in the European Union: Electoral Rights and the Restructuring of Political Space (Cambridge University Press, 2007).

19 R Bauböck, 'Expansive Citizenship—Voting beyond Territory and Membership' (2005) 38(4) Political Science \& Politics 683, p 685.

${ }^{20}$ See Article 12 of the Anglo-Irish Treaty (or, as it was styled, the "Anglo-Irish Treaty - Articles of Agreement for a Treaty between Great Britain and Ireland') signed on 6 December 1921, which provided for such a Commission. The Irish Boundary Commission established under this article met during 1924 and 1925. Its 1925 Report proposing minor changes to the provisionally drawn border proved so politically controversial when leaked to the press in advance of publication that the UK, Free State, and Northern Irish governments agreed to suppress it and to confirm the existing provisional location of the border. See for more detail, P Murray, The Irish Boundary Commission and its Origins 1886-1925 (UCD Press, 2011).

21 See Central Statistics Office, Population and Migration Estimates - April 2009 (22 September 2009), which contains figures showing immigration levels from 1987 onwards. 1992 was the first year in which Ireland experienced a positive balance in net inward migration. This then became a constant trend from 1996 onwards, reversing, however, temporarily between 2010 and 2015 with the onset of the Irish economic crisis. See Central Statistics Office, Population and Migration Estimates (CSO Statistical Release, 23 August 2016). 
accepted with alacrity by Irish officials keen to control aliens and keep 'Bolshevists' at bay. ${ }^{22}$ Various practical and political reasons pointed to the desirability of a CTA between the two jurisdictions. Then, as now, the impracticality of trying to police a border on the island of Ireland was clear, as were Unionist objections to controls being imposed on journeys between Northern Ireland and Great Britain. The economic advantages of refraining from the imposition of border controls as well as the attractiveness of such a stance to Northern nationalists may also have suggested themselves. Finally, maximised free movement of labour clearly suited both parties. ${ }^{23}$

Notwithstanding the strongly nationalist tenor of the subsequent 1937 Constitution, Ireland remained a member of the British Commonwealth until the enactment of the Republic of Ireland Act 1948 in Ireland and the Ireland Act 1949 in the United Kingdom, which gave effect to the declaration of a republic and Irish withdrawal from the Commonwealth in the domestic laws of both jurisdictions. ${ }^{24}$

Other than customs controls, entry checks between Ireland, on the one hand, and either Britain or the United Kingdom as a whole, on the other, have only existed temporarily for reasons of national security. The first period of such controls was during World War II, and for several years after, when checks were introduced between the island of Ireland and mainland Britain, beginning in September 1939, with a British travel permit being required for travel in either direction from June 1940 onwards. ${ }^{25}$ The second was for periods during the 'Troubles' in Northern Ireland, when political violence there led to the physical blocking of some so-called 'unauthorised' border crossings between Ireland and Northern Ireland, and the introduction of security checks at others. Passport controls did not form part of the latter restrictions, however, with no checks being introduced between Ireland and mainland Britain. The cooperation that existed between the two states' security forces was considerable, and extradition arrangements between the two states strengthened over time, ${ }^{26}$ perhaps somewhat ironically, however, only reaching their fullest extent with the introduction of the European Arrest Warrant, which effectively subsumed previous bilateral arrangements. Suppression of customs controls between Ireland and the United Kingdom-including along the Northern Irish

\footnotetext{
22 Ryan, note 10 above, p 856.

23 See B Ryan, The Implications of UK Withdrawal for Immigration Policy and Nationality Law: Irish Aspects (ILPA EU Referendum, 18 May 2016) Position Paper 8, pp 1-2. See also T McGuinness and M Gower, The Common Travel Area and the Special Status of Irish Nationals in UK Law (House of Commons Library, June 2017) Briefing Paper No. 7661, pp 8-9.

${ }^{24}$ Consideration was briefly given by the British government to retaliating for the 1948 Act by altering the favourable treatment of Irish citizens in the UK but nothing came of this. See eg D McCullough, Declaring the Republic (Ep 4/6), available at historyhub.ie/david-mccullagh-johncostello-declaring-the-irish-republic-1948.

25 See Ryan, note 10 above, p 857. Hence Minister for External Affairs Frank Aiken TD's observation to the Dáil in a debate on 23 April 1952 that 'there was a certain stop or restraint on people leaving [Ireland] for Britain or other countries during the war and up to 7th April, 1952'.

26 P O'Higgins, 'Irish Extradition Law and Practice' (1958) 34 British Yearbook of International Law 274, p 302. See generally, P Charleton, 'Extradition from Ireland to the United Kingdom' (1989) 53(2) Journal of Criminal Law 235.
} 
border - took place as a result of a European-wide initiative: the drive for a Single Market, which led to the abolition of systematic customs checks from 1 January 1993. ${ }^{27}$ Increased European integration required the adoption of 'opt-outs' to facilitate the two states retaining their own border controls, and arrangements relating to the freedom of travel between the two states.

\section{B. National Legislative Frameworks}

A striking feature of the CTA has been the degree of informality associated with its creation and existence. The arrangements for the CTA are not based on any international treaty between the two states, ${ }^{28}$ and the description 'common travel area' (used in quotation marks and without the use of capitals) was originally less a legal term of art than an informal expression deployed as a shorthand description of the arrangements put in place between the two states. Its arrangements have only gradually become more solidly legally grounded over the decades. One may thus identify a certain ongoing dissipation of informality and crystallisation into legal rules of originally less legally rigid arrangements. This is just one example of the evolving nature of the CTA, a framework in which the level of integration involved has waxed and waned over the years.

The relevant rules now apply in each of the respective domestic legal orders through the operation of statutory or sub-statutory rules, with the two states each operating their own immigration controls. Prior to the adoption of legal instruments to give legal effect to the CTA, officials from the British Home Office and the Irish Department of Justice engaged in an exchange of letters with the purpose of reaching agreement on how the operation of the CTA would be managed by the two jurisdictions. The administrative agreement constituted by this informal exchange of letters took place instead of a formal legal agreement, avoiding any political difficulties that might otherwise have arisen from Ireland operating in a 'single immigration unit' applying British rules. ${ }^{29}$

Today, the legislative underpinning for the CTA differs as between the two jurisdictions - one of several respects in which an absence of uniformity exists between the two states concerning the CTA. A lack of equality is seen too in the unequal mutual influence exerted by the two legal systems on one another by virtue of the CTA. Irish immigration law and rules concerning visas have come strongly under the influence of UK law. In British law, ${ }^{30}$ the means used to give effect to the CTA derive

27 See in this regard the announcement made by Paymaster-General John Cope MP in the House of Commons (3 June 1992).

28 B Ryan, 'United Kingdom' in I Higgins and K Hailbronner (eds), Migration and Asylum Law and Policy in the European Union: FIDE 2004 National Reports (Cambridge University Press, 2004), p 431.

29 E Meehan, 'Freedom of Movement: The Common Travel Area between Ireland and Britain and the Treaty of Amsterdam' in S Ghatak and A Showstack (eds), Migration and Mobility: The European Context (Palgrave Macmillan, 2001) 124, p 128, where she notes the 'warm political and diplomatic understanding of each other's problems, on the one hand, and, on the other, studied indifference to the Irish public when the occasion demanded'. In fact, however, keeping matters out of the public eye was clearly a strategy used on both sides of the Irish Sea. Ibid, pp 130-31.

30 Including in this regard the law of Northern Ireland. 
from two sources: the Immigration Act 1971 and the Immigration (Control of Entry through Republic of Ireland) Order 1972, adopted immediately prior to both states' entry into the then EEC. Section 1(3) of the 1971 Act provides, in particular, that

arrival in and departure from the United Kingdom on a local journey from or to any of the Islands (that is to say, the Channel Islands and Isle of Man) ... or the Republic of Ireland shall not be subject to control ... and in this Act the United Kingdom and those places, or such of them as are not so excluded, are collectively referred to as 'the common travel area'.

The 1972 Order (as subsequently amended) lists categories of persons who are deemed to have leave to remain in the UK for three months on arrival from Ireland. These include EU nationals with free movement rights as well as those who do not require a visa to enter the UK (so-called 'non-visa nationals') as long as these are lawfully in Ireland. Above and beyond the 1971 Act and the 1972 Order, the United Kingdom also has 'Immigration Rules', a set of rules laid down by the Home Secretary regarding practices to be followed in administering the Immigration Acts' regulation of entry into and stay in the United Kingdom. The Rules are contained in a statement which has been laid before Parliament. Paragraph 15 of these Rules sets out policy guidelines regarding how the CTA is supposed to work in practice from a United Kingdom perspective. ${ }^{31}$ The Order makes provision for persons arriving in the UK from Ireland, including non-British and non-Irish nationals (thereby including all other EU nationals, and third country nationals who do not need a visa for normal entry into the UK). To this extent, therefore, some of the British rules implementing the CTA do not exclusively concern Irish citizens only. The United Kingdom also has exceptional provisions in the form of the Immigration (Entry Otherwise than by Sea or Air) Order $2002,{ }^{32}$ which provides for the land border between Ireland and Northern Ireland. The 2002 Order is primarily concerned with addressing illegal immigration by third country nationals rather than being concerned with British or Irish citizens.

There has been some reluctance in Ireland to put the CTA on a visible formal legal basis, ${ }^{33}$ perhaps because of the sensitivity of the political issues involved. Indeed, as has already been noted, its earliest origins lay in an agreement on administrative cooperation-ie, the agreement by the UK not to introduce passport controls in exchange for agreement by the Irish Free State and its officials to participate in the British immigration control system. ${ }^{34}$ This was, however, soon backed up by appropriate provision in Irish immigration law. Hence Article 1 of the Aliens Order 1925 exempted aliens coming from Great Britain or Northern Ireland from the need to obtain leave of an immigration officer to land, ${ }^{35}$ subject to certain exceptions (such as a time limit imposed on their staying in Great Britain or Northern Ireland having

\footnotetext{
31 Immigration Rules: Part 1 (United Kingdom Home Office, 6 April 2014).

32 The Immigration (Entry Otherwise than by Sea or Air) Order 2002 (No 1832).

33 See Maher, note 10 above.

34 Ryan, note 10 above, p 856.

35 SR \& O 1925 No 760.
} 
expired, or their having been illegally present there, or being the subject of a deportation or expulsion order there). Subsequently, United Kingdom nationals were exempted by Order from the application of the Aliens Act 1935 (which for long provided the regulatory basis for much of Irish immigration law). ${ }^{36}$

The period of the Second World War (and some time beyond this) likewise saw special rules exempting British and Irish nationals regarding the need to seek leave to enter the country. ${ }^{37}$ After the war, Ireland unilaterally allowed certain aliens to enter freely from Britain from December 1946 onwards, ${ }^{38}$ continuing the exemption from immigration law for United Kingdom nationals effected in $1935 .^{39}$ The means by which this was done-the Aliens Order 1946-remained a key element of Irish immigration control thereafter. In 2004, however, the Irish High Court delivered its judgment in Leontjava and Chang $v$ Director of Public Prosecutions. ${ }^{40}$ In it, Judge Mary Finlay Geoghegan declared a provision of the Aliens Order 1946 (which had been inserted by a 1975 Order) ${ }^{41}$ to be ultra vires, in essence because it had been created in circumvention of the constitutionally established process for the creation of primary legislation. ${ }^{42}$ This cast "serious doubt on the validity of all statutory provisions dealing with the control of entry to, and stay in, the state by non-nationals', ${ }^{43}$ leaving open the possibility of a further challenge to the state's ability to control its own border. Within days, the Immigration Act 2004 was passed by the Oireachtas (Irish Parliament) as an emergency response to this unexpected judgment. ${ }^{44}$ Ironically, some months later, the Supreme Court reversed the High Court decision. ${ }^{45}$ Nevertheless, the 2004 Act remains in place. Section 11 of the Act-as amended by Section 34(a) of the Civil Law (Miscellaneous Provisions) Act 2011-now governs the entry of nonnationals into the state, requiring inter alia, that every person (other than a person under the age of 16 years) landing in the state shall be in possession of a valid passport or other equivalent document. 'Non-nationals' excludes UK nationals, however. ${ }^{46}$ It also excludes Irish citizens and persons with free movement rights under EU law. ${ }^{47}$

\footnotetext{
36 See Aliens (Exemption) Order 1935 (SR \& O 1935 No 80) and again in 1946. (See Aliens Order 1946, Art 1 (SI No 395 of 1946)).

37 See Aliens Order 1943 (SR \& O 1943 No 169).

38 See further Ryan, note 10 above, p 858.

39 Initially, this was shared with nationals of certain Commonwealth states. Subsequently, it was restricted to British nationals. See Aliens (Amendment) (No 2) Order 1999 (SI No 24 of 1999); Aliens Exemption Order 1999 (SI No 97 of 1999); Ryan, note 10 above, p 862.

40 [2005] 1 ILRM, [2004] 1 IR 591, [2004] IESC 37.

41 Aliens (Amendment) Order 1975 (SI No 128 of 1975).

42 The High Court further held that Section 2 of the Immigration Act 1999 was unconstitutional in that it attempted to delegate legislative functions to the Executive.

${ }^{43}$ Minister of State at the Department of Justice, Equality and Law Reform Brian Lenihan TD, speaking on the second stage of the Immigration Bill 2004 in the Dáil on 30 January 2004.

44 Immigration Act 2004 (No 1).

45 See [2004] IESC 37.

46 See Immigration Act 2004, Sec 1(1); Immigration Act 1999, Sec 1(1).

47 See Immigration Act 2004, Sec 11(5) (as substituted by Civil Law (Miscellaneous Provisions) Act 2011, Sec 34.
} 
Section 4(3)(h) of the 2004 Act is of interest in that it permits Irish immigration officers to refuse permission to a non-national to land, or be, in the state on the grounds that that individual intends to travel to the UK and would not qualify for admission if he/she arrived there from another state. In other words, it permits the Irish state to enforce, remotely, United Kingdom rules regarding the landing of nonnationals.

\section{European Union Law}

The principles governing fundamental economic freedoms have been central to the pursuit of integration at EU level. ${ }^{48}$ With the need to dismantle barriers to the free movement of workers, goods, capital, and services, the removal of frontier controls in any form between EU Member States logically evolved into a key objective. ${ }^{49}$ However, since the adoption of such a policy within the framework of the then European Communities would have required unanimous agreement, ${ }^{50}$ which was not going to be forthcoming given the United Kingdom's determination to maintain border controls with mainland Europe, ${ }^{51}$ the eventual abolition of border controls came about thanks to a non-EEC measure: the 1985 Schengen Agreement. The initial Schengen Agreement in 1985 was reached between five of the then ten Community Member States (Belgium, France, West Germany, Luxembourg, and the Netherlands). The United Kingdom, Ireland, Italy, Denmark, and Greece - the other Community Member States at the time-were not party to the initial Agreement, although the last three subsequently joined the system. ${ }^{52}$

\footnotetext{
48 See generally C Barnard, The Substantive Law of the EU: The Four Freedoms, 5th ed (Oxford University Press, 2016).

49 See, for example, in this regard, the reference in the preamble to the Treaty on European Union, which declares the signatory states to be 'resolved to facilitate the free movement of persons', Article 3(2) TEU ('the free movement of persons is ensured in conjunction with appropriate measures with respect to external border controls, asylum, immigration and the prevention and combating of crime'), Article 26(2) TFEU ('internal market shall comprise an area without internal frontiers in which the free movement of goods, persons, services and capital is ensured'), and Article 67(2) TFEU (Chapter V on Area of Freedom, Security and Justice, Title I on General Provisions).

50 See generally Article 48 TEU.

51 A good indication of the attitude towards border controls of the British Prime Minister at the time of the negotiation of the Schengen Agreement, Margaret Thatcher, was provided in her well-known Bruges discourse. See in relation to this, J Palmer, 'Thatcher Sets Face Against United Europe' (The Guardian, 21 September 1988). See generally regarding the United Kingdom position, A Wiener, 'Forging Flexibility - The British "No" to Schengen' (1999) 1(4) European Journal of Migration and Law 441, p 441. See also J Schutte, 'Schengen: Its Meaning for the Free Movement of Persons in Europe' (1991) 28(3) Common Market Law Review 549, p 550.

52 Greece and Italy are today full parties to the Schengen Agreement. Denmark also participates. However, Article 3 of Protocol (No 19) on the Schengen Acquis Integrated into the Framework of the European Union provides that 'the participation of Denmark in the adoption of measures constituting a development of the Schengen acquis, as well as the implementation of these measures and their application to Denmark, shall be governed by the relevant provisions of the Protocol on the position of Denmark'. Article 4 of Protocol (No 22) on the position of Denmark duly provides that:
} 
For the United Kingdom, non-adherence to the Schengen developments was a choice. For Ireland - with the bulk of travellers leaving the state either travelling to, or through, the United Kingdom-non-adherence was effectively forced by circumstances, including the impossibility of simultaneously being in two mutually exclusive free travel areas: the CTA and Schengen. Subsequently, the United Kingdom and Ireland have opted to remain outside the Schengen Area, and instead retained their own border controls, which are subject to domestic rather than EU-level arrangements. ${ }^{53}$ As for the Schengen states, ${ }^{54}$ whilst the Schengen system has largely eliminated border controls between them, it is today much more than a system for the abolition of border controls. It now additionally involves a sophisticated system of visa and asylum policies, border, judicial, and police cooperation. ${ }^{55}$

Prior to the entry into force of the Treaty of Amsterdam, ${ }^{56}$ no legal provision in international or EU law referred to the CTA. However, at this juncture, in order to safeguard the CTA, reference was made to it in EU primary law in a Protocol, ${ }^{57}$ under which the United Kingdom and Ireland could maintain their own border controls, including those with fellow Member States. ${ }^{58}$ The United Kingdom and Ireland were permitted to 'continue to make arrangements between themselves relating to the movement of persons between their territories (the "Common Travel Area")', while still being obliged to respect Treaty free movement rights, and a guarantee provided that no provision of the Treaties would affect any such arrangements. The Protocols relating to free movement of persons were built upon at Nice, ${ }^{59}$ although not in a manner that had a material effect on the CTA. With the

\section{(F'note continued)}

1. Denmark shall decide within a period of six months after the Council has decided on a proposal or initiative to build upon the Schengen ... whether it will implement this measure in its national law. If it decides to do so, this measure will create an obligation under international law between Denmark and the other Member States bound by the measure.

2. If Denmark decides not to implement a measure of the Council as referred to in paragraph 1, the Member States bound by that measure and Denmark will consider appropriate measures to be taken.

53 For more on the opt-outs generally from a non-legal perspective, see R Adler-Nissen. Opting Out of the European Union: Diplomacy, Sovereignty and European Integration (Cambridge University Press, 2014).

${ }^{54}$ Four of which are now non-EU states, namely, Norway, Iceland, Liechtenstein, and Switzerland.

55 See for a relatively recent examination, G Cornelisse, 'What's Wrong with Schengen? Border Disputes and the Nature of Integration in the Area without Internal Borders' (2014) 51(3) Common Market Law Review 741, p 743.

56 See in this regard, G Barrett, 'Justice and Home Affairs - an Overview' in B Tonra (ed), Amsterdam - What the Treaty Means (Institute of European Affairs, 1998).

57 The Treaty of Amsterdam came into effect in 1999 with an annexed Protocol on the application of certain aspects of Article 7a of the Treaty establishing the European Community to the United Kingdom and to Ireland.

58 B Laffan and J O'Mahony, Ireland and the European Union (Palgrave Macmillan, 2008), p 173.

59 By the adoption of a new Protocol on Article 67 of the EU Treaty (governing administrative cooperation between the Member States' administrations over 'visas, asylum, immigration and other policies related to free movement of persons'). 
Treaty of Lisbon, both states expanded their opt-outs beyond the Schengen acquis, ${ }^{60}$ the continuance of the CTA, ${ }^{61}$ and to all justice and home affairs matters. ${ }^{62}$ The three Protocols relating to the United Kingdom and Ireland allow either state to selectively choose policies within a Union framework on justice and home affairs generally. ${ }^{63}$

Despite the close connections between the United Kingdom and Ireland, the two states have had very different kinds of relationship with the EU. The United Kingdom, a larger, more populous and more influential state, with a history of empire and an ongoing relationship with its Commonwealth, has had a difficult relationship with the European integration project from the beginning. ${ }^{64}$ It has tended to have a decided preference for a closed border system with all states, except Ireland, and possesses firmly held views on how borders should work. ${ }^{65}$ It benefits from the widest range of opt-outs when it comes to matters pertaining to justice, home affairs, border, and immigration laws. ${ }^{66}$ Ireland, a far smaller Member State, has tended to enjoy a warmer relationship with the Union (although one nonetheless punctuated by two defeats for referendums designed to facilitate ratifications of EU treaties). ${ }^{67}$ The same level of hostility to the Schengen agenda of the abolition of border controls is not encountered in Ireland. However, for practical reasons-not least of which is the desire to keep the border with Northern Ireland as open as possible-preservation of the CTA is regarded as an Irish policy priority. Given that simultaneous membership of two non-entirely-overlapping open-border zones is obviously a logical impossibility, ${ }^{68}$ this in turn excludes participation in the suppression of borders via the

${ }^{60}$ Protocol (No 19) on the Schengen acquis integrated into the framework of the European Union.

61 Protocol (No 20) on the application of certain aspects of Article 26 of the Treaty on the Function of the European Union to the United Kingdom and to Ireland.

62 Protocol (No 21) on the position of the United Kingdom and Ireland in respect of the Area of Freedom, Security and Justice.

${ }^{63}$ See for a discussion of the impact of the Treaty of Lisbon in this regard, J Monar, 'The Area of Freedom, Security and Justice' in A von Bogdandy and J Bast (eds), Principles of European Constitutional Law, 2nd ed (Hart Publishing, 2009), p 569.

${ }^{64}$ See generally on this theme, H Young, This Blessed Plot: Britain and Europe from Churchill to Blair (Overlook Press, 1998); D O'Ceallaigh and P Gillespie (eds), Britain and Europe: The Endgame - An Irish Perspective (Institute of International and European Affairs, 2015); and P Gillespie (ed), Blair's Britain - England's Europe (Institute of European Affairs, 2000).

${ }^{65}$ Described as 'pragmatic' in M Hedemann-Robinson, 'The Area of Freedom, Security and Justice with Regard to the UK, Ireland and Denmark: The "Opt-in Opt-Outs" Under the Treaty of Amsterdam' in D O'Keeffe and P Twomey (eds), Legal Issues of the Amsterdam Treaty (Hart Publishing, 1999), p 291.

${ }^{66}$ Followed by Denmark and Ireland. The UK is also (with Denmark) exempt from any obligation or commitment to adopt the euro. See Protocol on Certain Provisions Relating to the United Kingdom of Great Britain and Northern Ireland, agreed by the Member States at Lisbon.

${ }^{67}$ More generally, see S Kingston, 'Ireland's Options after the Lisbon Referendum: Strategies, Implications and Competing Visions of Europe' (2009) 34(3) European Law Review 455; J O'Brennan, 'Ireland Says No (Again): The 12 June 2008 Referendum on the Lisbon Treaty' (2009) 62(2) Parliamentary Affairs 258.

${ }^{68}$ Unless all states which are parties to each are prepared to eliminate border controls with all states which are members of the other. 
Schengen system. This practical need to prioritise the CTA has thus created very real constraints on policy choice for Ireland. Once accepted, other choices have ceased to be available-arguably the most significant being full participation in Schengen. Indeed one of the principal considerations for Ireland when partaking in anything to do with the Schengen acquis is the consequence an action may have for the CTA. ${ }^{69}$

The CTA Protocol involved the United Kingdom and Ireland each receiving an 'opt-out' enabling the two states to continue to operate the CTA, ${ }^{70}$ notwithstanding the integration of the Schengen Agreement into EU law, thereby using 'flexibility' or 'variable geometry' to protect the integrity of the CTA. ${ }^{71}$ The corollary of the guarantee to the two states was found in Article 3 of the same Protocol, which provided that the other Member States were permitted to put in place an external border control for transit of persons entering from the United Kingdom or Ireland. ${ }^{72}$ The reluctant nature of Irish participation in these arrangements was visible in the guarantees to Ireland-although not those made to the United Kingdom-being made conditional on the continuation of the CTA. ${ }^{73}$ For Ireland, the choice not to enter the Schengen area was less a philosophical preference than a practical choice for one open-border area over another, maximising freedom of travel in and out of Ireland. This was further underlined by a Declaration, of which the Intergovernmental Conference that agreed to the Treaty of Amsterdam took note: ${ }^{74}$

Ireland declares that it intends to exercise its right under Article 3 of the Protocol on the position of the United Kingdom and Ireland to take part in the adoption of measures pursuant to Title IIIa of the Treaty establishing the European Community to the maximum extent compatible with the maintenance of its Common Travel Area with the United Kingdom. Ireland recalls that its participation in the Protocol on the application of certain aspects of Article $7 \mathrm{a}$ of the Treaty establishing the European

${ }^{69}$ See C Costello, 'European Community Asylum and Immigration Policy-Making - Integrating a Role for the Oireachtas?' in G Barrett (ed), National Parliaments and the European Union: The Constitutional Challenge for the Oireachtas and Other Member State Legislatures (Clarus Press, 2008), p 213. Note also in this regard Declaration by Ireland on Article 3 of the Protocol on the position of the United Kingdom and Ireland, discussed above.

70 B Ingoldsby, 'Free Movement - A Department of Justice Perspective' in N Hyland (ed), The Free Movement of Workers within the European Union (Irish Centre for European Law, 1999), pp 23-26. The full name of this Protocol was the Protocol on the application of certain aspects of Article 7a of the Treaty establishing the European Community to the United Kingdom and to Ireland.

71 J Handoll, 'Ireland', in I Higgins and K Hailbronner (eds), Migration and Asylum Law and Policy in the European Union: FIDE 2004 National Reports (Cambridge University Press, 2004), p 181.

72 Article 3, paragraph 1 provided that: the other Member States shall be entitled to exercise at their frontiers or at any point of entry into their territory such controls on persons seeking to enter their territory from the United Kingdom or any territories whose external relations are under its responsibility for the same purposes stated in Article 1 of this Protocol, or from Ireland as long as the provisions of Article 1 of this Protocol apply to Ireland.

73 Article 2 of the CTA Protocol.

74 Declaration by Ireland on Article 3 of the Protocol on the position of the United Kingdom and Ireland. 
Community reflects its wish to maintain its Common Travel Area with the United Kingdom in order to maximise freedom of movement into and out of Ireland.

The according of Treaty recognition for the CTA was a striking development, ${ }^{75}$ given the earlier reluctance of the British government and the Irish government to crystallise the CTA arrangements in international treaty form, and their earlier preference in establishing it to rely on administrative rather than legal measures as its basis. The opting-out policy contributed to and rendered more visible a special category of law. ${ }^{76}$ What is now Protocol 20 acknowledges the special travel arrangements that have been bilaterally put in place between the United Kingdom and Ireland, with Article 2 providing that

the United Kingdom and Ireland may continue to make arrangements between themselves relating to the movement of persons between their territories ('the Common Travel Area'), while fully respecting the rights of persons referred to in Article 1, first paragraph, point (a) of this Protocol.

Accordingly, as long as they maintain such arrangements, the provisions of Article 1 of this Protocol shall apply to Ireland under the same terms and conditions as for the United Kingdom. Nothing in Articles 26 and 77 of the Treaty on the Functioning of the European Union, in any other provision of that Treaty or of the Treaty on European Union or in any measure adopted under them, shall affect any such arrangements.

Other protocols concerning the United Kingdom and Ireland are also of relevance. The Schengen Protocol itself underwent revisions in the Treaty of Lisbon, ${ }^{77}$ but, as has already been seen, continues to allow both the United Kingdom and Ireland to remain outside the Schengen system, while still having the option of participating in elements of the Schengen acquis (subject to the unanimous approval of all of the Schengen Member States). Both the United Kingdom and Ireland thus enjoy a relatively privileged position under EU law, particularly as regards the Schengen acquis. The 'optout, opt-in' arrangement is not one which is offered to new entrants on their accession to the Union; they are required to sign up to eventual full Schengen participation. The United Kingdom and Ireland, in contrast, are permitted to operate external border checks. They also abstain from full participation in the Schengen acquis in several other respects as well. The Schengen Protocol allows each state to participate in particular aspects of the Schengen acquis, provided however that the Council approves such participation unanimously. ${ }^{78}$ Both jurisdictions tend to favour opting into those elements of Schengen concerned with security and the repression of criminality. They

75 Ryan, note 10 above, p 855.

76 See PJ Kuijper, 'Some Legal Problems Associated with the Communitarisation of Policy on Visas, Asylum and Immigration under the Amsterdam Treaty and Incorporation of the Schengen Acquis' (2000) 37(2) Common Market Law Review 345.

77 Note in this regard, IGC 2007 Mandate (Council of the European Union, 11218/07, June 2007), Part IV.

${ }^{78}$ See, providing further guidance in this regard, United Kingdom $v$ Council, C-77/05, EU:C:2007:803, and United Kingdom v. Council, C-137/05, EU:C:2007:805, discussed in the text above. 
have also opted into measures concerning illegal immigration and asylum at EU level. ${ }^{79}$ Both states have been reluctant to opt into other measures: most obviously, those concerning borders, but also those concerning migration and visa policy.

Protocol 21 on the position of the United Kingdom and Ireland in respect of the area of freedom, security and justice offers to both states the possibility of opting into measures in the justice and home affairs policy field, covering asylum, immigration, border controls, combating crime, racism and xenophobia, police and judicial cooperation and both criminal law matters and civil law cooperation. Protocol 21 originated at the time of the agreement of the Treaty of Amsterdam. It was subsequently expanded at Lisbon to comprehend a broader exclusion for both states from justice and home affairs. United Kingdom adherence to the wider exclusion was in response to what it saw as an unwelcome growth in the role of EU institutions in policy formation in the justice and home affairs field. ${ }^{80}$ Ireland's exclusion, on the other hand, was a precautionary response by one relatively small common law jurisdiction to the self-imposed exclusion of another much larger such jurisdiction (the United Kingdom) from justice and home affairs cooperation. ${ }^{81}$ It may be added, however, that during the subsequent lengthy public debates during which the Irish electorate first rejected in referendum a constitutional amendment facilitating the Treaty of Lisbon's ratification in 2008, before subsequently reversing this vote in 2009, Protocol 21's 'opt-out with an opt-in arrangement' ensured that justice and home affairs issues remained uncontroversial and featured little in the debate, becoming, as was noted by one former official who was interviewed, 'the dog that did not bark' during the ultimately successful second constitutional referendum campaign. ${ }^{82}$

\footnotetext{
79 For example, the two states have opted-in to the Common European Asylum System ('CEAS').

${ }^{80}$ See in this regard, G Barrett 'The United Kingdom Opt-Out under Protocol 36 Agreed at Lisbon the Implications for Ireland', invited address to the United Kingdom House of Lords Select Committee on EU Affairs, 13 February 2013 (Joint Session of EU Sub-Committee E on Justice, Institutions and Consumer Protection (chaired by Lord Bowness) and EU Sub-Committee F on Home Affairs, Health and Education (chaired by Lord Hannay of Chiswick)).

${ }^{81}$ See in this regard the article by then Irish Minister for Foreign Affairs, D Ahern, 'Ireland Not Slavishly Following Britain in Treaty Opt-out' (Irish Times, 13 October, 2007), in which the Minister observed:
}

\begin{abstract}
We were very comfortable with the justice provisions of the constitutional treaty agreed in 2004 . We were confident that the combined negotiating weight of Ireland and Britain would have been sufficient to ensure respect for the essential features of our shared common law tradition. The British decision to absent itself from justice measures under the Reform Treaty would have left Ireland in quite a different position. As one of a handful of small member states with a common law tradition, it could have been very difficult for Ireland acting alone to shape future proposals in a direction palatable to us.
\end{abstract}

Faced with this new situation, the Government had to weigh up its options and to decide on the best course of action. The mandate for the current negotiations gave Ireland the opportunity to join the new opt-out on criminal law and police co-operation.

See also Barrett, note 80 above.

82 Interview with retired senior Department of Justice official, 1 September, 2011. See for some reflections in this regard, Fahey, 'Swimming in a Sea of Law', note 10 above. 


\section{Judicial Developments}

The CTA has seen only a limited number of court rulings in the courts of the United Kingdom and Ireland, and the Court of Justice of the European Union. Legislation covering the CTA in the United Kingdom was, for example, upheld by the Northern Ireland High Court in Alinta, ${ }^{83}$ where it was noted that the CTA applied in relation to citizens of the two jurisdictions and not in relation to third country nationals. ${ }^{84}$ A significant decision was delivered by the High Court of Ireland in 2011 in Pachero $v$ Minister for Justice and Equality. ${ }^{85}$ Here it was held (analogously to the ruling in Alinta in the High Court in Northern Ireland) that the CTA, from an Irish legislative perspective, was directly for the benefit of British and Irish citizens, not of third country nationals, including other EU and European Economic Area ('EEA') nationals. ${ }^{86}$ The High Court of Ireland in a separate judgment just months earlier had also referred to 'those who are not Irish or British citizens (and who accordingly cannot avail of the benefits of the CTA agreement between Ireland and the United Kingdom)'. ${ }^{87}$ The CTA arrangements are thus not regarded as being for the benefit of third country nationals, even if they are legal residents. Judicial rulings are one thing, however, enforcement is quite another. Enforcing the rules on the CTA's internal border for persons other than citizens of the United Kingdom and Ireland is problematic, given the numerous uncontrolled roads between Northern Ireland and Ireland. ${ }^{88}$

In judicial proceedings at EU level, issues concerning the relations between Schengen and non-Schengen states in the European Union have given rise to a number of rulings by the Court of Justice of the European Union. ${ }^{89}$ Whilst no case specifically concerning Protocol 20 has arisen before the Court, cases with potential

${ }^{83}$ Alinta, Re Application for Judicial Review, [2006] NIQB 61 (High Court of Justice in Northern Ireland).

${ }^{84}$ The United Kingdom courts have time and again upheld the lawfulness of the United Kingdom's legislation on the CTA. See Kaya v SSHD, [1991] Imm Ar 572 (Court of Appeal), Emmanson (Fyneface), Re Judicial Review, [2010] NICA 35 (Court of Appeal in Northern Ireland), R v Governor of Ashford Reman Centre, Ex parte Bouzagou, [1983] Imm Ar 69 (Court of Appeal (England and Wales)).

${ }^{85}$ Daniella Fernandez Pachero and Roberth Monero Choma $v$ Minister for Justice and Equality, Ireland and Attorney General, [2011] IEHC 491 (High Court of Ireland); Butler, note 10 above.

86 'Foreigners May Not Avail of Republic-North Visa-Free Travel' (Irish Times, 24 December 2011).

87 Ejerenwa $v$ the Governor of Cloverhill Prison and the Minister for Justice, Equality and Law Reform, [2011] IEHC 351 (High Court of Ireland).

${ }^{88}$ Remarkably, it has been reported that there are more border crossings between Ireland and Northern Ireland than on the whole of the EU's eastern border (275, compared to 137 land border crossings on the east of the EU). See 'Reality Check: Ireland's Border and Brexit' (BBC, 16 August 2017).

${ }^{89}$ Rui Alberto Pereira Roque $\nu$ His Excellency the Lieutenant Governor of Jersey, C-171/96, EU:C:1998:368; Kaba v Secretary of State for the Home Department, C-466/00, EU:C:2003:127; Secretary of State for the Home Department $v$ Akrich, C-109/01, EU:C:2003:491; Zhu and Chen v Home Secretary, C-200/02, EU:C:2004:639; Metock v Minister for Justice, Equality and Law Reform, C-127/08, EU:C:2049. 
implications for the CTA have. Cases C-77/05 United Kingdom v Council ${ }^{90}$ and C-137/05 United Kingdom v Council, ${ }^{91}$ regarding the Protocol on the Schengen acquis involved an attempt by the United Kingdom-joined on both occasions by Ireland - to annul two Council Regulations, respectively establishing Frontex, ${ }^{92}$ and concerning common passport standards for Member States. ${ }^{93}$ The rulings_-in which the challenges failed-have been variously described as having upheld the coherence of the Schengen acquis, disincentivised 'pick and choose' approach by the two states, ${ }^{94}$ and displayed relative dissatisfaction with the opt-out arrangements, ${ }^{95}$ and even as having amounted to a push from the Court steering the Member States away from their opt-outs, ${ }^{96}$ and towards participation in all Union measures to the greatest possible extent. ${ }^{97}$ In a more recent post-Lisbon judgment, the Court fleshed out whether Member States with opt-outs-like those of the United Kingdom and Ireland-could informally cooperate to a limited extent with other Member States on the Schengen acquis on border control, ${ }^{98}$ answering in the affirmative. This has opened up the possibility for both the United Kingdom and Ireland to engage in further cooperation with Schengen states, without being reduced to the status of mere third states. The debate about 'opt-outs' for Member States continues to be a sensitive matter for the Court of Justice to deal with. ${ }^{99}$

Case law on the Protocol on the CTA has had little scope to develop as the CTA itself is provided for by national legislation, not EU law. EU law merely recognises

\footnotetext{
90 United Kingdom v Council, C-77/05, EU:C:2007:803.

91 United Kingdom v Council, C-137/05, EU:C:2007:805.
}

92 European Agency for the Management of External Borders. Council Regulation (EC) No 2007/2004. For more on the legal basis of this body, see R Mungianu, 'Frontex: Towards a Common Policy on External Border Control' (2013) 15(4) European Journal of Migration and Law 359.

93 Council Regulation (EC) No 2252/2004.

94 M Fletcher, 'Schengen, the European Court of Justice and Flexibility under the Lisbon Treaty: Balancing the United Kingdom's "Ins" and "Outs", (2009) 5(1) European Constitutional Law Review $71, \mathrm{p} 72$.

95 The two judgments dealt with similar issues in terms of the Protocols in Union law, and were issued separately on the same day. See JJ Rijpma, 'Case C-77/05, United Kingdom v. Council, Judgment of the Grand Chamber of 18 December 2007, Not yet Reported, and Case C-137/05, United Kingdom v. Council, Judgment of the Grand Chamber of 18 December 2007, Not yet Reported' (2008) 45(3) Common Market Law Review 835, p 842.

96 The United Kingdom lost a third case on their own in this regard. See United Kingdom v Council, C-482/08, EU:C:2010:631.

97 Partial participation already takes place with the request of the United Kingdom to engage in this having been approved by the Council in Council Decision of 29 May 2000 Concerning the Request of the United Kingdom of Great Britain and Northern Ireland to Take Part in Some of the Provisions of the Schengen Acquis (2000/365/EC): [2000] OJ L131/43, and that of Ireland in Council Decision of 28 February 2002 Concerning Ireland's Request to Take Part in Some of the Provisions of the Schengen Acquis (2002/192/EC): [2002] OJ L64/20.

98 Spain v Parliament and Council, C-44/14, EU:C:2015:554.

99 For a discussion in this regard, see the viewpoint of (then Advocate General) P Mengozzi, 'The Court of Justice Faced with Opting-Out Member States' (2015) 6(4) New Journal of European Criminal Law 546. 
the CTA without seeking to regulate it. An interesting case decided by the Court concerning the particularly close relationship between the CTA states was Chen. ${ }^{100}$ This case actually involved movement within the United Kingdom (from mainland Britain to Northern Ireland) in order to avail of Irish, and thus, indirectly, EU citizenship rights offered by Ireland to those born in Northern Ireland. The case therefore did not directly concern a cross-border issue-but movement from the United Kingdom to Ireland raised very similar legal issues. The Court of Justice ruled that there had been no abuse of rights from the perspective of EU law, by virtue of the Chens having moved to the island of Ireland for the purpose of availing of citizenship rights.

\section{REFORMS AND CHALLENGES}

The CTA has now been in existence for nearly a century. In that time, it has not remained unchanged, with developments having come about in both its legal foundations and practical operation. Various pressures are now acting on the CTA which have already led to reforms and can be expected to give rise to more. This section of the article is intended to review both these pressures and the reforms which have resulted to date.

Commercial and economic factors have certainly been a factor in bringing about change. So too have security concerns in a world alert as never before to the risks of terrorism. The most significant increase in coordination between the United Kingdom and Ireland, the introduction of the British-Irish Visa Scheme and the reasons for its introduction are considered in this section. The potentially greatest challenge in the CTA's history-the now-rapidly approaching occurrence of Brexit is also reflected on.

\section{A. Pressures for Reform in a New Millennium}

Of the factors which have led to pressure for the reform of the CTA in recent years, commercial pressures are not the least. As a Member State with a much smaller economy than its closest neighbour, Ireland has sought to benefit from whatever business opportunities that proximity to the United Kingdom presents. Its approach to the CTA has reflected this. Due to their separate border management policies and visa requirements, an obvious danger has existed of both the UK and Ireland missing out on visitors from third states and the associated opportunities and benefits. Hence, in July 2011 - shortly before the 2012 London Summer Olympic games-the Irish government announced its own Visa Waiver Programme unilaterally waiving the need to have an Irish visa to visit the state if a person arriving in Ireland was from one of an eventual eighteen different states and had already obtained a visa to enter the

\footnotetext{
100 Kunqian Catherine Zhu and Man Lavette Chen v Secretary of State for the Home Department, C-200/02, EU:C:2004:639. For a commentary, see E Sharpston, 'Citizenship and Fundamental Rights - Pandora's Box or a Natural Step towards Maturity?' in P Cardonnel, A Rosas and N Wahl (eds), Constitutionalising the EU Judicial System: Essays in Honour of Pernilla Lindh (Hart Publishing, 2012), p 260.
} 
United Kingdom. ${ }^{101}$ The Visa Waiver Programme's sole purpose was unashamedly that of generating enhanced revenue from visitors arriving from markets with a developing or emerging status. On these terms, with a huge rise seen in the number of visitors in its initial years of implementation, the Visa Waiver Programme was regarded as an instant success from an Irish perspective. ${ }^{102}$ However, such acceptance of visas works only in the one direction-United Kingdom visas are accepted in Ireland, and not vice versa. As such, it can be seen as an example of inequality in the mutual influence exerted by the Irish and UK legal systems, and in particular, visa regimes on one another, in the context of the CTA.

A further pressure has been the United Kingdom's increased focus on national security, particularly since the 7/7 London bombings in 2005, which has meant the British government in recent years has focused on strengthening the UK's external borders. The CTA, with its 'open' border to Ireland, was easily identified as a weak link in the United Kingdom's border-control mechanisms. The draft version of what became the Borders, Citizenship and Immigration Act 2009 consequently initially proposed implementing passport controls in sea and air links between Great Britain and Ireland (although not along the land frontier between Ireland and Northern Ireland) in order to 'plug a critical gap' ${ }^{103}$ in the United Kingdom's border. Ultimately, such proposals - which would have impacted an estimated fifteen million travellers a year and effectively involved ending a large number of benefits of the CTA for them-were abandoned. ${ }^{104}$ Instead, the British government sought a working arrangement with Irish authorities in enhancing security for entry into the CTA and on its external borders. ${ }^{105}$

The story of the 2009 Act provides evidence that the benefits of the CTA are of a rather more fragile nature than might sometimes be supposed. Other evidence of this point is not difficult to come by. Despite the existence of the CTA, Ryanair, an airline company, when transporting passengers between the United

101 Initially announced as applying only to short-stay visas, it was however extended to holders of other visas. See Irish Short-Stay Visa Waiver Programme Information Note (Irish Naturalisation and Immigration Service, March 2012). The Scheme is now governed by Article 3(d) of the Immigration Act 2004 (Visas) Order 2014 (SI No 473 of 2014). The Immigration Act 2004 (Visas)(Amendment) Order 2016 has subsequently extended the application of this provision until 31 October 2021.

102 See in this regard eg Department of Justice and Equality, 'Immigration in Ireland - 2013 in Review' (December 2013).

103 A Travis, 'UK-Irish Travellers to Face Passport Checks' (The Guardian, 15 January 2009). Proposals to introduce passport checks for those flying from Belfast to the rest of the United Kingdom had been dropped only after being forcibly opposed both Conservatives and Ulster Unionists. The intended imposition of border controls was also to have applied to travellers between Britain and the Isle of Man and the Channel Islands.

104 See 'Thousands of Travellers Entering Ireland from UK Will Not Be Included in New Passport Checks' (Irish Independent, 8 April 2015).

105 Minister for Justice, Equality and Law Reform, D Ahern, and Home Secretary, J Smith, Joint Statement Regarding the Common Travel Area (Irish Department of Justice, Equality and Law Reform and United Kingdom Home Office, 24 July 2008). For analysis of subsequently introduced arrangements, see Common Travel Area: Review of New Arrangements at Northern Ireland Seaports (United Kingdom Border Agency, July 2012). 
Kingdom and Ireland, and even within the same jurisdiction, has long required persons to produce a means of identification, which in practice involves the production of a passport. ${ }^{106}$ This led to a Private Members' Bill being introduced in the lower house of the Irish Parliament, the Dáil, in 2014 by a member of parliament, ${ }^{107}$ with the aim of preventing carriers from requiring unnecessary identification checks on qualified persons travelling within the two states that form the CTA. ${ }^{108}$ Ryanair objected to the loosening of permissible identification requirements, ${ }^{109}$ and the government used its majority to prevent the Bill from becoming law, ${ }^{110}$ citing drafting concerns, but also highlighting 'the changed nature of travel security, especially the heightened awareness of the security risks associated with airline travel since 9-11'.111

In late 2011, a Joint Statement Regarding Co-operation on Measures to Secure the External Common Travel Area Border was signed by the British Minister of State for Immigration and the Irish Minister for Justice and Equality. ${ }^{112}$ Its objectives included facilitating legitimate travel with the CTA, preventing abuse, and identifying further ways to enhance the existing ties between the two states on border issues. It envisaged a work programme of data sharing and electronic border management systems, ${ }^{113}$ eventually allowing for exchanges of information on visa applications from a small number of specified states between United Kingdom Border Agency ('UKBA') and Irish Naturalisation and Immigration Service ('INIS'), ${ }^{114}$ with Ireland updating its data collection system for biometric data to meet British standards. Whilst the enactment of measures for the purposes of implementing this Joint Statement was underway in 2012, the Northern Irish Executive-which has no immigration powers within its devolved competencesought, with a view to increasing tourist revenue in its territory, the permission of

\footnotetext{
106 Fahey, 'Swimming in a Sea of Law', note 10 above, p 680.

107 Freedom of Movement (Common Travel Area) (Travel Documentation) Bill 2014, proposed by Terence Flanagan TD.

108 Qualifying persons within the CTA without the need of a passport being citizens of the EEA.

109 Letter from M O'Leary, Chief Executive, Ryanair, 'Re Common Travel Area to Terence Flanagan TD' (23 June 2014).

110 See M O'Halloran, 'Government Rejects Bill on Passport-Free Ryanair Travel' (Irish Times, 13 November 2015).

111 See statement on behalf of the government by Deputy Damien English, Minister of State at the Department of Education and Skills, 13 November 2015, on the proposed second reading of the Bill in the Dáil.

112 Minister of State for Immigration, D Green, and Minister for Justice and Equality, A Shatter, 'Joint Statement Regarding Co-Operation on Measures to Secure the External Common Travel Area Border' (United Kingdom Home Office and Irish Department of Justice and Equality, 20 December 2011).

113 See in this regard, Deputy Damien English, Minister of State at the Department of Education and Skills, 13 November 2015, speaking on the proposed second reading of the Freedom of Movement (Common Travel Area) (Travel Documentation) Bill 2014 in the Dáil.

114 These included Bangladesh, China, Ghana, India, Iran, Nigeria, Pakistan, and Sri Lanka. On the Scheme, see P O'Connell and C Joyce, International Migration in Ireland, 2012 (UCD Geary Institute Discussion Paper Series April 2013).
} 
the British government to allow a deviation from visa policy for Northern Ireland, so as to allow holders of Irish visas to enter Northern Ireland lawfully. The British government refused, basing its rationale on security and resource grounds. $^{115}$

\section{B. An Increase in Coordination: The British-Irish Visa Scheme}

Historically, notwithstanding the existence of the CTA, if a third country national held a short-stay visa for one of the jurisdictions, ${ }^{116}$ this did not give him or her the right of lawful entry into the other. ${ }^{117}$ Originally, the passport- and visa-free travel provided under the CTA was supposedly limited to citizens of just the two states, ${ }^{118}$ despite the different legislative provisions in the two jurisdictions. Thanks to their opt-outs in relation to justice and home affairs matters, the two states have retained significant powers over the admission of third-country nationals to their respective territories, and can make further arrangements between themselves. States in the Schengen system have coordinated short-term visa policies, but this is not the case as regards the United Kingdom and Ireland. More specifically, Article 77(2)(a) TFEU envisages a common policy on visas and other short-stay residence permits. However, Article 2 of Protocol 21 on the position of the United Kingdom and Ireland in respect of the area of freedom, security, and justice effectively gives both states an opt-out from this, which means that they can issue their own short-term visas.

A 2013 study commissioned by the two governments on wider joint interests- the Joint British-Irish Economic Study by PA Consulting Group-made recommendations for measures to alleviate barriers, suggesting mutual visa recognition would be beneficial for both states. ${ }^{119}$ This led to the British-Irish Visa Scheme ('BIVS'). This Scheme was officially announced in 2014 , jointly by the British Home Secretary ${ }^{120}$ and the Irish Minister for Justice and Equality. ${ }^{121}$ Their intention was to create a policy of mutually recognisable visas, permitting third country nationals, whether visiting the United Kingdom or Ireland, and whether for business, leisure, or other stated purposes, to travel within the CTA on a single visa, accepted by both jurisdictions. This facilitation of travel for visitors between the United Kingdom and Ireland was designed to permit an arrangement such that, in the words of a former

115 Official Report (Hansard) - Visa Waiver Programme, Vol 74, No 3 (Northern Ireland Assembly, 20 March 2012).

116 Excluding EU, EEA, and Swiss citizens.

117 This has been the case up until now, but will change pending full implementation of the BritishIrish Visa Scheme, discussed later in the article.

118 And those of the Isle of Man and the Channel Islands.

119 'East/West Co-Operation - Taoiseach E Kenny and Prime Minister D Cameron Welcome the Publication of the Joint British-Irish Economic Study by PA Consulting Group' (MerrionStreet.ie Irish Government News Service, 18 July 2013).

120 Home Secretary Theresa May 'Home Secretary's Speech on Chinese Nationals' Visas' (Home Office, 16 June 2014).

121 'Minister Fitzgerald Announces Launch of Joint Visa Initiative between Ireland and the United Kingdom' (MerrionStreet.ie - Irish Government News Service, 16 June 2014). 
Irish Minister for Justice, 'the outer perimeter of the CTA would operate like a miniSchengen zone ... [representing] a historic breakthrough in the manner in which the CTA operates'. ${ }^{122}$

While the British-Irish Visa Scheme was adopted with one eye to increasing the security of the external CTA border, economic considerations also clearly supplied much of the motivation for it, in particular, the idea of increasing the number of visitors from the continent of Asia, by eliminating the then off-putting burden for travellers from third countries of applying for separate British and Irish visas. This requirement stood in sharp contrast to the single Schengen visa that covered particular non-EU nationals when travelling throughout most of Europe. The Scheme opened up to Chinese nationals living in China in October 2014, followed by Indian nationals living in India in February 2015, allowing, for the first time people from some third states to enter the United Kingdom with a visa from Ireland alone, and without needing a separate British visa. ${ }^{123}$ To date, no other states have been added. Under the Scheme, which was intended to have a gradual roll out, only one BritishIrish Visa Scheme visa will be needed by third country nationals who are covered. In practical terms, rather than issuing a joint British-Irish visa or a neutral visa, issued jointly by the two states, each state will retain its own visa-issuing process, with visas inserted into successful applicants' passports with a BIVS code inserted. Applicants for visas under the Scheme must apply for the visa from the state they enter first, and the Scheme does not therefore represent an open licence to access either state, but rather one subject to this restriction. ${ }^{124}$ There are further limits. Although they form part of the CTA, Crown Dependencies of the United Kingdom-ie, the Isle of Man and the Channel Islands-are excluded from the Scheme. Furthermore, the Scheme applies only to short-stay visas, ${ }^{125}$ and not to other kinds such as student or longterm work visas. The possibility of a long-stay visa under reciprocal arrangements, much less one leading to residence or citizenship rights has not been proposed within the scope of the CTA, and the prospects of such a development appears remote. Such an advanced level of integration would have involved unnecessary complications at such an early stage in the process of reciprocal arrangements being put into place. Assuming the success of the Scheme, the pilot stage will be rolled out to a more extensive list of nationalities. Absent the supervening threat posed by Brexit, the establishment of the British-Irish Visa Scheme, and then its extension might possibly have allowed one to envisage the effective abolition of border controls of any kind

\footnotetext{
122 Minister for Justice and Equality, A Shatter, Department of Justice and Equality: Common Travel Area (5 November 2013).

123 Official Report (Hansard) - Common Travel Visa, Vol 94, No 4 (Northern Ireland Assembly, 8 April 2014).

124 According to the British-Irish Visa Scheme Information Note produced by the Irish Department of Foreign Affairs and Trade: 'If you have an Irish short stay visa and you want to also visit the United Kingdom you must travel to Ireland first. If you have a British visit visa and you want to also visit Ireland you must travel to the United Kingdom first'. The departmental site also notes that visa-holding persons returning to Ireland following a visit to the UK will not require a re-entry visa. See www.inis. gov.ie/en/INIS/Pages/British+Irish+Visa+Scheme.

125 Allowable up to 90 days on an eligible Irish visa, and 180 days on an eligible United Kingdom visa.
} 
between the two states, mimicking to this extent the Schengen arrangements, and representing further integration between Britain and Ireland (an objective pursued outside EU law). The Scheme may in any case also be regarded as an example of the kind of engrénage that can be generated by a close level of cooperation between states, such as that involved in the CTA.

The British-Irish Visa Scheme was created in the light of improved political relations between the two states. Nevertheless, the United Kingdom had previously sought for some time to tighten borders in order to increase security and ensure that any travel between the two jurisdictions by non-nationals was legitimate. Prior to the announcement of the British-Irish Visa Scheme, there had never been a unified visa scheme in place for the United Kingdom and Ireland. A non-EU citizen would have previously needed separate distinct short-stay visas to enter the United Kingdom, and Ireland. In practical terms, the possibility existed of unlawfully entering one of the states having obtained a valid visa for the other, given the open border between the two states - an anomaly never addressed before the adoption of the new scheme.

The British-Irish Visa Scheme was given legal effect through statutory instruments in each jurisdiction. In the United Kingdom, this resulted in the Immigration (Control of Entry through Republic of Ireland) (Amendment) Order 2014, ${ }^{126}$ amending the Immigration (Control of Entry through Republic of Ireland) Order 1972. ${ }^{127}$ This allows permitted individuals to enter the United Kingdom without a British visa, but instead, with an Irish visa with a British-Irish Visa Scheme endorsement, once that person has permission to be in Ireland at the time of arriving in the United Kingdom. The Irish government adopted parallel Statutory Instruments to give legal effect to the political agreement in the Irish legal order, amending the Immigration Act 2004 (Visas) Order 2012, ${ }^{128}$ with the Immigration Act 2004 (Visas) Order 2014, ${ }^{129}$ and subsequently the Immigration Act 2004 (Visas) (Amendment) Order 2015. ${ }^{130}$ Further legal alterations will be required in the future to enable further third countries to come within the British-Irish Visa Scheme arrangements. It may be noted that for such a significant step on border matters, the British-Irish Visa Scheme has been effected in each jurisdiction with a relatively minor legal instrument, requiring no more than a Minister's signature, rather than by adopting legislation subject to a full vote of the members of the respective national parliaments, debated in an open and transparent manner. There is something of a context for this. Ireland has a history of implementing important changes in immigration and labour market policy-

\footnotetext{
126 The Immigration (Control of Entry through Republic of Ireland) (Amendment) Order 2014 (SI No 2475).

127 The Immigration (Control of Entry through Republic of Ireland) Order 1972 (SI No 1610).

128 Immigration Act 2004 (Visas) Order 2012 (SI No 417/2012).

129 Immigration Act 2004 (Visas) Order 2014 (SI No 473/2014).

130 Immigration Act 2004 (Visas) (Amendment) Order 2015 (SI No 175/2015); Minister for Justice and Equality, F Fitzgerald, Visa Agreements (Houses of the Oireachtas (Irish Parliament), 8 July 2014). In answer to a Dáil question on the changes, the Irish Minister for Justice and Equality, F Fitzgerald, explained that the implementation of the British Irish Visa Scheme for the Common Travel Area required a small number of amendments of a technical nature to be made to Statutory Instrument 417 of 2012 .
} 
including implementing significant EU Directives-by statutory instrument or otherwise with very little debate. ${ }^{131}$ As has already been noted, the statutory underpinning of its immigration legislation is provided by an Act which was rushed through its parliament in 2004 to overrule a High Court judgment.

The question can nonetheless be asked of why the CTA has seen such constant resort to practice instead of law, ministerial regulations instead of statutes, and statutes instead of constitutional provisions. The likeliest explanation of such an approach seems to be that it represents an attempt to reconcile securing the practical need for a common travel area with the realisation of the considerable political sensitivities regarding such a step, and in ongoing efforts to avoid this. Thus, in Ireland, the reality of economic dependence on a more powerful neighbourincluding the need for the safety valve of emigration - combined with the need for cooperation to assure social and commercial life on both sides of the border to continue unabated, collided with understandably fiery nationalistic rhetoric of a country which had only just won its independence, and in which public opinion objected fiercely to what it saw as the external imposition of a border. In the UK, a similar need regarding the Irish border plus the clear economic and political benefits of allowing high levels of Irish emigration, on the one hand, collided with the politically contentious idea of the UK privileging the citizens of an Ireland gradually becoming ever less tied to the UK than many of its Commonwealth partners.

By way of a concluding comment on the British-Irish Visa Scheme, it may be noted that the CTA has never been a common visa area, nor does the British-Irish Visa Scheme make it one. Reciprocal visa recognition is all that it entails. It is a significant step given that differences that have existed in the respective regimes concerning third country nationals in the past. ${ }^{132}$ However, mutual recognition is not a common visa system. That much said, the Scheme will provide the two states with future opportunities to build further cooperation, to expand the mutual recognition of each other's visas, and perhaps even recognising short-stay Schengen visas. It will certainly require constant monitoring and further amending statutory instruments in both jurisdictions as it expands. In Ireland, the Scheme will supersede the earlier Visa Waiver Programme.

\section{Brexit}

By far the greatest recent risk posed to the CTA has come from the Brexit referendum of 23 June 2016. The vote of the United Kingdom electorate by a 52\%-48\% majority to exit the European Union was a political earthquake both for the United Kingdom and for Ireland. ${ }^{133}$ That it was an unwelcome one on the island of Ireland as a whole

\footnotetext{
131 See eg N Hyland, 'Recognition of Qualifications of Migrant Workers - The Irish Situation' in N Hyland (ed), The Free Movement of Workers within the European Union (Irish Centre for European Law, 1999), p 66.

132 This was seen, for example, in the Pachero judgment in which it was noted that Bolivian citizens did not need a visa to enter Ireland, but did need one in order to enter the United Kingdom.

133 For a good account of the impact both actual and potential on Ireland, see T Connelly, Brexit and Ireland: The Dangers, the Opportunities and the Inside Story of the Irish Response (Penguin, 2017).
} 
could be seen both in the 56\%-44\% majority against Brexit in Northern Ireland, ${ }^{134}$ and in the open encouragement of the Irish government in the pre-referendum campaign to those of its citizens having a vote in the UK referendum to vote on the 'Remain' side. The referendum result carries with it a myriad of potential risks: to cross-border trade and cooperation; to funding levels for Northern Ireland's agriculture sector (and, to a lesser extent, Ireland's); as well as to the extent of influence at European level-for Northern Ireland (within a politically diminished UK), but also for Ireland which now faces the prospect of being deprived of a frequent, although not invariable, ally in EUlevel debates. Issues regarding the Northern Ireland border itself were not the least of these concerns: some, but not all of these related to the CTA. Others related to the important issue of its context: membership of both the Single Market and the Customs Union by both the UK and Ireland rendered possible the single market and customs union between the two jurisdictions on the island of Ireland.

As noted, the open-border zone constituted by the CTA has never been governed by a formal international treaty of any description, but has existed in practice more or less continuously from the foundation of the Irish state. In contrast, the border-suppressing benefits of, respectively: (1) the abolition of customs controls; and (2) the creation of the single market are of far more recent vintage. Notwithstanding the existence of the CTA, customs controls were, from 1923 onwards, applied at entry points between the Irish State and the UK (including along the Northern Ireland border), right up until their abolition on 1 January 1993. Such controls were applied, first and most obviously, in order to exact customs duties-tariffs-from those moving goods between the two states. Secondly, however, controls were also applied in order to ensure the enforcement of health, safety, and other standards. Member States of a customs union can, after all, maintain all sorts of national regulations (be these health standards, agricultural controls, minimum product standards, etc) and goods entering a national market need to be checked for compliance with these. Such checks provided the justification for continued customs controls along the Northern Irish border until the Single European Market emerged in 1993, and this notwithstanding the fact that between 1973 and 1992, the UK and Ireland were in a full customs union with each other. ${ }^{135}$ Only in a single market are such health, agricultural, and consumer standards harmonised or mutually recognised on a comprehensive basis. Where the benefits of a

\section{(F'note continued)}

There are numerous accounts of the framework of Brexit and its impact on the United Kingdom. Useful works include $\mathrm{K}$ Armstrong, Brexit Time: Leaving the EU - Why, How and When? (Cambridge University Press, 2017); M Dougan (ed), The UK after Brexit: Legal and Policy Challenges (Intersentia, 2017); and F Fabbrini (ed), The Law and Politics of Brexit (Oxford University Press, 2017).

134 Divided although this was between the two communities with nationalists voting primarily to remain, and unionists voting primarily for Brexit. A May 2018 study showed however that the proportion of Northern Irish voters opposed to Brexit had risen sharply since the referendum to $69 \%$, indicating a high level of cross-community concern about the implications of the Brexit process (See $\mathbf{J}$ Garry, K McNicholl, B O'Leary and J Pow, 'Northern Ireland and the UK's Exit from the EU - What Do People Think? (Economic and Social Research Council/UK in a Changing Europe, 2018); 'Brexit Support Plummets in Northern Ireland as 69\% Back Remain' (The Independent, 21 May 2018).

135 See now Article 28 TFEU which provides: 'The Union shall comprise a customs union which shall cover all trade in goods and which shall involve the prohibition between Member States of customs 
customs union are added to those of a single market, there ceases to be a need for customs checks. This is why systematic customs checks along the border could be abolished at the beginning of 1993. At that point, the then EEC added the benefits of the Single European Market to those of the Customs Union. Europe has thus made a considerable contribution to the lack of controls on travel between Ireland and the UK, and, more particularly, to the relative invisibility of the border between Northern Ireland and Ireland. This contribution to reducing border controls in Europe, however, is over seventy years younger than the CTA. ${ }^{136}$

The ending of another inconvenience to cross-border travel and trade came with the abolition of security checkpoints on the Northern Ireland border. These originated (at least in their semi-permanent form) during the period of political violence known as the Northern Ireland 'Troubles' which began at the end of the 1960s, and persisted until the late 1990s. The ending of this period of political violence rendered such controls redundant and the 1998 Good Friday agreement contained a commitment on the part of the UK government to the removal of security installations along the Northern Ireland border, which was subsequently given effect to. ${ }^{137}$ Nonetheless - and notwithstanding the consistent policy of the EU ${ }^{138}$ in favour of the reduction of the need for inspections and in favour of minimising their intrusiveness ${ }^{139}$ - the capacity for customs arrangements to cause disruptions for people (and not just goods) is clear, and the potential need for customs checkpoints to require police or army protection, thus bringing with them the need for renewed and potentially politically obtrusive security arrangements, is also considerable. As noted, 'no amount of tariff reductions, technological innovation, risk management or cross-border cooperation will eliminate the disruption [caused by enforcement of the external frontier of the customs union] entirely, ${ }^{140}$ with all the attendant economic, social, and political risks (not excluding smuggling and violent attacks on such posts) this carries with it.

(F'note continued)

duties on imports and exports and of all charges having equivalent effect, and the adoption of a common customs tariff in their relations with third countries'.

136 See generally 'Special Deal to Stop Return of Border Controls not Possible' (Irish Times, 20 February 2017); K O'Rourke, 'British Public Wakes up to the Reality of Free Trade: The History of Anglo-Irish Trade Shows Distinctions Between Customs Unions, the Single Market and Free Trade' (Irish Times, 6 December 2017). See also House of Lords European Union Committee, Brexit: UK-Irish Relations $\left(6^{\text {th }}\right.$ Report of Session 2016-17, 12 December 2016) HL Paper 76, p 23; G Barrett, 'Would Staying in a Customs Union after Brexit Avoid a Hard Border with Ireland?' (The Conversation, 1 March 2018).

137 See Part 8 (under the rubric 'Security'), Point 2(iii) of the Multi-Party Agreement set out in Annex I to the Agreement between the Government of the United Kingdom of Great Britain and Northern Ireland and the Government of Ireland of 10 April 1998.

138 Which has exclusive competence regarding the customs union. See Article 3(1)(a) TFEU, and Article 2 TFEU regarding the significance to be accorded to exclusive competence.

139 Eg with widespread use of electronic systems, distinctions between commercial and private traffic and eased customs formalities for certain economic operators. See further M Dougan, "The "Brexit" Threat to the Northern Irish Border: Clarifying the Constitutional Framework' in M Dougan (ed), The UK after Brexit: Legal and Policy Challenges (Intersentia, 2017), p 57.

140 Ibid, p 59. 
Brexit is not without implications for the CTA as well, however. One significant issue is the question of whether UK exit from the EU will bring to an end the legal protection which is provided under EU law for the CTA by Article 2 of Protocol 20. The argument that this would indeed be the case has garnered support, ${ }^{141}$ and is based on the wording of Article 2 which stipulates that as long as arrangements for the CTA are maintained, the border-control authorising provisions of the Protocol shall apply to Ireland under the same terms and conditions as for the United Kingdom. ${ }^{142}$ Dougan has argued vehemently against the conclusion that the Protocol's protection for Ireland ends with UK membership of the EU. He bases this on the fact that border controls are a shared competence and that neither Ireland nor the UK has adhered to the Schengen goal of abolishing internal passport controls. Instead, their competence to maintain the CTA and to retain border checks has been explicitly recognised by Protocol 20. ${ }^{143}$ According to Dougan,

to suggest that Ireland's own competences are somehow entirely derived from or contingent upon those of the UK, and only in the latter's capacity as a Member State, would not only be an inappropriate interpretation of Union law which seems difficult to reconcile with respect for Irish sovereignty. It would also be tantamount to allowing the UK to rewrite Ireland's constitutional and substantive position under the Treaties, merely through the UK's own choices about membership, regardless of the views of Ireland itself, and altogether outside the ordinary procedure for amending Union primary law. ${ }^{144}$

Moreover, regardless of how Protocol No 20 is interpreted, Protocols $19,{ }^{145} 21,{ }^{146}$ and $23,{ }^{147}$ separately provide protection for Irish competence concerning border controls. To some extent the question is moot, since the EU, the UK, and Ireland alike have all expressed an interest in ensuring the survival of the CTA. Hence the British Prime Minister's September 2017 speech in Florence, which purported to set the course of Brexit announced that both the EU and the UK had 'committed to protecting the Belfast Agreement and the Common Travel Area'. ${ }^{148}$ At the time

${ }^{141}$ It has for instance been argued for by a former Irish Attorney General. See P Gallagher, 'The Alternatives to UK Membership of the EU' in The Legal Implications of Brexit (unpublished paper delivered to the Irish Business and Employers' Confederation and the Irish Centre for European Law, 5 May 2016).

142 Emphasis added.

143 Dougan, op. cit., p 62, n 140.

144 Ibid, p 63.

145 Protocol (No 19) on the Schengen Acquis Integrated into the Framework of the European Union. See in particular Articles 4 and 5 providing for Ireland and the UK opting in to provisions of the Schengen acquis and proposals and initiatives to build upon them.

146 Protocol (No 21) on the Position of the United Kingdom and Ireland in Respect of the Area of Freedom, Security and Justice. See in particular Articles 1 and 2 thereof exempting the UK and Ireland from the operation and applicability of the provisions of Title V of Part Three TFEU (concerning the area of freedom, security, and justice).

147 Protocol (No 23) on External Relations of the Member States with Regard to the Crossing of External Borders, the objective of which is to avoid prejudice to Member State competence to negotiate or conclude agreements with third countries as long as they respect Union law.

148 The British Prime Minister had already declared soon after the referendum result that 'there is a strong will on both sides [with Ireland] to preserve it [the CTA]'. See press statement after meeting 
of writing, the most recent document of relevance-the November 2018 European Commission Brexit Task Force Draft Agreement on the Withdrawal of the United Kingdom of Great Britain and Northern Ireland from the European Union and the European Atomic Energy Community ${ }^{149}$ - provides in a Protocol that: ${ }^{150}$

1. The United Kingdom and Ireland may continue to make arrangements between themselves relating to the movement of persons between their territories (the 'Common Travel Area'), while fully respecting the rights of natural persons conferred by Union law.

2. The United Kingdom shall ensure that the Common Travel Area and associated rights and privileges can continue to apply without affecting the obligations of Ireland under Union law, in particular with respect to free movement for Union citizens and their family members, irrespective of their nationality, to, from and within Ireland. ${ }^{151}$

Insofar as disagreement occurs in relation to border-related issues, rather than concerning the CTA itself, the focus of disagreement now principally concerns the context of the CTA, and more specifically, the question of how to avoid the Brexit process leading to the reintroduction of customs controls along the Northern Ireland frontier, given the professed intention of the United Kingdom to leave the EU Customs Union and the Single Market. ${ }^{152}$ A final version of the Withdrawal Agreement was agreed by

\section{(F'note continued)}

between Prime Minister May and then Irish Taoiseach Enda Kenny on 26 July 2016 at Downing Street (emphasis added).

149 TF50 (2018) 55 (14 November 2018), available at https://ec.europa.eu/commission/sites/betapolitical/files/draft_withdrawal_agreement_0.pdf.

150 Article 5 of the Protocol on Ireland/Northern Ireland.

151 This reflects and elaborates on paragraph 54 of the 8 December 2017 Joint Report from the Negotiators of the European Union and the United Kingdom Government on Progress During Phase 1 of Negotiations under Article 50 TEU on the United Kingdom's Orderly Withdrawal from the European Union, according to which:

Both Parties recognise[d] that the United Kingdom and Ireland may continue to make arrangements between themselves relating to the movement of persons between their territories (Common Travel Area), while fully respecting the rights of natural persons conferred by Union law. The United Kingdom confirms and accepts that the Common Travel Area and associated rights and privileges can continue to operate without affecting Ireland's obligations under Union law, in particular with respect to free movement for EU citizens.

Note now however the speech made by Prime Minister May in Belfast on 20 July 2018 at Belfast's Waterfront Hall, the text of which is available at https://www.gov.uk/government/speeches/pm-belfastspeech-20-july-2018.

152 See in this regard eg, the Florence speech by the British Prime Minister, and for the most recent developments in this regard at the time of writing, see J Blitz, 'Theresa May's New Customs Gamble' 
the EU and the UK in November 2018 to allow time for the European Parliament to decide whether to give its (required) consent, the Council to conclude it, ${ }^{153}$ and the UK Parliament to have a 'meaningful vote' on a draft of the text as well as legislating for the implementation of the Agreement. ${ }^{154}$

Brexit is not without the capacity to give rise to further difficulties for the CTA. One key issue post-Brexit seems likely to be reconciling the existence of free movement rights under EU law with the existence of the CTA. Differing visa arrangements between Ireland and the UK, coupled with a lack of checks on the Northern Ireland border and (in an earlier time) at airports have meant that there has been for decades a risk that third country nationals allowed into one CTA state could access the second such state without too much difficulty: whether by crossing the Northern Ireland border (where checks are extremely rare even if technically legally possible), or by travelling between the two jurisdictions by ferry (where passport controls are rarely deployed). Depending on the approach to free movement adopted by the UK after Brexit, this situation is capable of changing since the numbers of persons entitled to travel freely into Ireland (using their free movement rights) but not travel freely into the UK (because of newly imposed restrictions) could rise dramatically. Should this in turn lead to a dramatic increase in the numbers travelling onwards to the UK illegally, this might be expected to provoke a negative reaction damaging to the CTA, such as the introduction of controls at UK airports and ports. Much, however, depends on the nature of free movement rights accorded to EU citizens in the UK in the wake of Brexit. Much would also depend on whether any significant use was made by EU nationals of their free movement rights to Ireland in order to enter the UK illegally (rather than entering the UK legally on short-term visas and then overstaying).

\section{CONCLUSION}

The CTA may be summarised as having a number of notable characteristics. Eight key features have been discussed in this article.

The first is its extraordinary durability. As has been seen, the CTA has existed since the foundation of the Irish state in December 1922, albeit with a period of partial suspension during World War II and for some years after, and thus may by now be said to have survived the Ireland-UK economic war of the 1930s, the Second World War, a lengthy period of economic openness and integration that included Irish and UK entry to and participation in what is now the European Union, and survived too, most recently, the rival attractions of the Schengen system. At present, the CTA appears likely to survive the process of Brexit. ${ }^{155}$

(F'note continued)

(Financial Times, 17 May 2018) and T Connelly, 'How the Eurosceptics Have Blown Brexit Talks Wide Open' (RTÉ, 5 May 2018).

153 See Article 50(2) TEU.

154 See in this regard Section 13 of the European Union (Withdrawal) Act 2018.

155 See in this respect, Article 2 of the Protocol on Ireland/Northern Ireland proposed by the European Commission Task Force for the Preparation and Conduct of the Negotiations with the UK under Article 50 TEU to be annexed to the draft Agreement on the withdrawal of the United Kingdom of Great 
A second feature of the CTA is the remarkable, although now gradually dissipating informality that has historically tended to be associated with the CTA's extent and operation from earliest times. Such informality has translated into a historic preference for administrative cooperation, exchanges of letters, for nonapplication of rules and statutory instruments over Acts of Parliament. Where statute law has been deployed, laws have historically sometimes-whether by accident or design-been drafted sufficiently obscurely to render unclear to all but the most expert how the rules will impact in practice. Such relative historical informality has brought with it certain concomitant advantages to governments for which its operation could give rise to considerable political discomfort-namely secrecy and flexibility. Secrecy benefited both Irish and UK administrations-Ireland, in concealing its ongoing economic dependence on its former colonial occupier and need for the safety valve of emigration to the United Kingdom to draw off workers for whom Ireland's initial relative economic failure and high birth rate meant (despite the nationalist rhetoric of the day) that the new state could never provide employment. Subsequently, when UK immigration reforms in the early 1960s formally left Irish immigrants in the same position as Commonwealth citizens-but in practice put them in a better situation - the UK government could and did use the lack of visibility of CTA arrangements to shield their then immigration law reforms against plausible charges of racism. ${ }^{156}$

A third phenomenon is what has been, in many respects, the evolving nature of the CTA. The degree of integration involved in the CTA has waxed and, it must be said, also waned over time. Hence it has developed considerably from the status of a mutually convenient arrangement which did not originally even have a formal name, ${ }^{157}$ and from being governed initially by a regime which included mere directions not to operate border controls to now being the object of a considerable number of legal provisions in both jurisdictions (as well as EU treaty-level references) and into an arrangement in which structures are becoming increasingly formalised.

The effect of other developments has been the opposite of consolidation, however. One example of this is that prior to World War II, there was a common list of states whose citizens would need visas. After the reactivation of the CTA in 1952, an approach involving mere coordination of visa lists replaced this (even if the respective lists have been kept very similar).

Another example is that in recent times, there has, to some extent, been a hollowing out of the benefits of the CTA. This has come about both through altered commercial practices and through changes in the law. Insofar as concerns commercial practices, the policy of one major airline, Ryanair-as has already been

\footnotetext{
(F'note continued)

Britain and Northern Ireland from the European Union and the European Atomic Energy Community (19 March 2018).

156 See for a good account of the reforms of this time, E Meehan, op. cit., pp 30-36, n 10.

157 Policy documents prior to the Amsterdam Treaty tended to refer to it in inverted commas as the 'common travel area'. See E Meehan, op. cit., n 10.
} 
noted-is to refuse access to flights between Ireland and the United Kingdom unless a passport is produced. To this extent, state-controlled passport checks have now been replaced (or in the case of flights into Ireland from the UK, supplemented) by private checks, eroding the supposed benefits of the CTA for citizens.

Changes in the law have also eaten into the benefits of the CTA however. In Ireland, the Aliens (Amendment) (No 3) Order 1997 empowered an immigration officer to examine aliens arriving in the state from Great Britain or Northern Ireland for the purpose of being given leave to land. ${ }^{158}$ While the definition of 'alien' in this context has never included British citizens, ${ }^{159}$ or, obviously, Irish citizens, the net effect of this development has been that both categories of person may now find themselves asked to demonstrate their nationality. Random checks on the Northern Irish border followed the 1997 Order, although they soon fell away due to sensitivity about accusations of racial stereotyping. ${ }^{160}$ However, arrivals by air in Irish airports from the United Kingdom find themselves processed through passport control along with arrivals from non-CTA points of origin. ${ }^{161}$ Again, erosion of the supposed benefits of the CTA is the result of this.

This leads us to another, fourth feature of the CTA: the striking fragility of its benefits. As just noted, the repudiation of state-conducted passport controls has proven itself vulnerable both to legal change and to replacement of state restrictions by private action and to the vagaries of airport design. As earlier pointed out, wartime exigencies led to the temporary suspension of the arrangement. More recently, the benefits of a completely open border with Northern Ireland have been doubted even if the termination of the CTA itself has not been suggested. ${ }^{162}$

A fifth phenomenon has been a certain degree of engrénage engendered by the CTA: the occurrence, in other words, of a chain of events, one deriving from another. Hence the creation of the CTA has led to flanking measures in fields such as police cooperation and immigration, and to a (largely) common and idiosyncratic approach to the Schengen System upon the agreement of the Treaty of Amsterdam in 1997 (which subsequently broadened out to the entire field of justice and home affairs cooperation).

A sixth noticeable feature has been the lack of uniformity between Ireland and the United Kingdom regarding a number of features of the CTA. These include (1) the national interests that are served by the existence of the CTA, which are somewhat different; and (2) the means used by the respective domestic legal systems to give effect to the CTA, with the UK tending to rely on nationality law, and Ireland tending

\footnotetext{
158 See Article 5(7)(a) of the Aliens Order 1946 as substituted by Article 3 of the Aliens (Amendment) (No 3) Order 1997.

159 See now Article 3 of the Aliens (Amendment) (No 2) Order 1999 (SI No 24 of 1999).

160 See Meehan, note 29 above, p 136.

161 See now in this regard, Section 11 of the Immigration Act 2004 as substituted by Section 34 of the Civil Law (Miscellaneous Provisions) Act 2011. EU citizens with free movement rights find themselves in a similar position. See now Section 11(5) of the Immigration Act 2004 as substituted by Section 34 of the Civil Law (Miscellaneous Provisions) Act 2011.

162 See eg 'Return of Border Checks "Inevitable” Post-Brexit Warn British MPs' (Financial Times, 1 December 2017).
} 
to use its immigration law. ${ }^{163}$ Linked to this lack of uniformity is (3) a certain lack of equality in the mutual influence exerted on the legal systems of the UK and Ireland on foot of the CTA. Ryan has correctly described the existing basis of the CTA as an arrangement 'with only limited reciprocity', and noted that the CTA has resulted in Irish immigration law and Irish visa law being strongly influenced by UK law, with little if any evidence of reciprocity. ${ }^{164}$ It should be added however, that if Ireland has historically subjected its rules in these areas to UK policy priorities, this was for long an easy price to pay in exchange for the benefits of the CTA, however, since it is only in relatively times that there has actually been immigration on any large scale into Ireland. Moreover, relying on mutual enforcement of visa and immigration rules has conveniently enabled Irish authorities to delegate the unpleasant task of enforcing the rules to the UK border authorities.

It follows from the foregoing that there is another, seventh, aspect to the CTA: the fact that Irish participation in the CTA comes at a price in terms of policy freedom. Meehan has denied that the CTA is symptomatic of a neo-colonial link between Ireland and the UK and observed that Ireland has successfully pursued its own interests throughout the history of the CTA. ${ }^{165}$ This may be true, but maintenance of the CTA has nonetheless in effect required that Irish visa and immigration rules to be kept broadly equivalent to those of the UK. Moreover, a price has also had to be paid by Ireland at European level, since participation in the CTA has precluded full Irish involvement in the Schengen system, pushing Ireland to the margins of European integration at the same time that its military neutrality already limits its ability to cooperate in the security field.

An eighth and final aspect of the CTA worthy of note is the importance of context to its significance. One example of this is given by the current ongoing debates about the necessity of securing the continued existence of a frictionless border notwithstanding Brexit, in which it has been highlighted that although the CTA has played a key part in establishing the current situation whereby one is scarcely aware of crossing the border between Ireland and Northern Ireland, it has nonetheless only been one ingredient of several that were necessary to achieve this situation, with other elements being the abolition of customs duties consequent on entry to the European Communities, in addition to the common consumer and safety standards that now form part and parcel of the Single European Market and which made possible the elimination of customs controls in 1993, and the elimination of security checks in the light of the 1998 Good Friday agreement. If Brexit removes any of these elements - such as the elimination of the need for customs controls-the importance of the CTA suffers a decline, since travellers not stopped to have their passports checked may nonetheless find themselves delayed by customs controls. Another example is that residence, social security, and rights to medical treatment of Irish immigrants to the United Kingdom take on a special significance in the context of a Brexit in which similar rights generally available to UK citizens are withdrawn.

163 Ryan, note 10 above, p 859.

164 Ibid, pp 865, 871, 873.

165 Meehan, op. cit., pp ix, 5, n 10. 
As the tide of EU rights ebbs in the wake of Brexit, some islets of rights guaranteed under the CTA may take on a renewed prominence. ${ }^{166}$

Overall, the CTA to date has appeared to involve a process of slow convergence of public policy between Ireland and the UK, and one not in tandem with developments in other Member States. Even without factoring in the prospect of Brexit, political realities within the United Kingdom, combined with the practical importance of the CTA to Ireland, have meant that any prospect of either the United Kingdom or Ireland adhering to the Schengen acquis in full and abandoning the CTA seems highly improbable for the foreseeable future. In practice, the CTA is of a distinctly limited nature. A CTA acquis of similar magnitude to the Schengen acquis has not developed, nor is there any intention at this juncture to follow such an ambitious path. As was illustrated by Pachero, ${ }^{167}$ a comprehensive common travel area does not exist. Neither is a unified visa system for the two jurisdictions yet in place. Subject to the outcome of the Brexit negotiations, decision making on the future of the CTA seems likely remain a bilateral intergovernmental affair, with EU institutional actors lingering on the side-lines. ${ }^{168}$

Today, over ninety years on from the birth of the CTA, societal changes have rendered the CTA more challenging to administer and less universal in the scope of the benefits it confers: both states have sizeable communities of persons who are not British or Irish citizens, and therefore, to whom the CTA is not applicable. One of the key flaws in current arrangements is that the CTA and its objectives are still not explicitly defined in the national law of either state, a situation perhaps influenced by the lack of any international agreement governing the CTA's existence. Some form of international agreement providing for the CTA and setting out its objectives might be a desirable development in the future, particularly if the CTA grows in importance. The British-Irish Visa Scheme has been one step towards further legal solidification of the CTA. There is, however, further room for future integration between the two states on short-term visas, and perhaps eventually for a coordinated or even integrated joint visa scheme for third country nationals.

While the creation of a single European external border must remain for now but the brave music of a distant drum, a more coherent legal framework between the United Kingdom and Ireland seems desirable for the CTA, for the sake of legal clarity and of more uniform rights. If, as now seems inevitable, the United Kingdom and Ireland are to deny their citizens the benefits of full membership of Schengen for the foreseeable future, it is arguable they should at least confer on them more solid legal rights than are presently accorded to them by the Common Travel Area.

\footnotetext{
166 See in this regard the interesting article by R Pells, 'UK-Ireland Deal on Post-Brexit Student Flows "Imperils EU links"' (Times Higher Education Supplement, 17 May 2018), in which it is noted that giving Irish undergraduate students alone of their EU-27 colleagues continued access to home fee status and loans in the UK could be discriminatory and violate EU law (and vice versa).

167 See Butler, note 10 above.

168 This of course, raises its own issues regarding the actors in such arrangements. See1 D Curtin and H Meijers, 'The Principle of Open Government in Schengen and the European Union: Democratic Retrogression?' (1995) 32(2) Common Market Law Review 391.
} 